This is an electronic reprint of the original article. This reprint may differ from the original in pagination and typographic detail.

Author(s): Stucki, Tobias; Woerter, Martin; Arvanitis, Spyros; Peneder, Michael; Rammer, Christian

Title: How different policy instruments affect green product innovation : A differentiated perspective

Year: $\quad 2018$

Version:

Please cite the original version:

Stucki, T., Woerter, M., Arvanitis, S., Peneder, M., \& Rammer, C. (2018). How different policy instruments affect green product innovation : A differentiated perspective. Energy Policy, 114, 245-261.

https://doi.org/10.1016/j.enpol.2017.11.049

All material supplied via JYX is protected by copyright and other intellectual property rights, and duplication or sale of all or part of any of the repository collections is not permitted, except that material may be duplicated by you for your research use or educational purposes in electronic or print form. You must obtain permission for any other use. Electronic or print copies may not be offered, whether for sale or otherwise to anyone who is not an authorised user. 


\title{
How Different Policy Instruments Affect Green Product Innovation: A Differentiated Perspective
}

\author{
Tobias Stucki ${ }^{1}$, Martin Woerter ${ }^{2}$, Spyros Arvanitis ${ }^{2}$, Michael Peneder ${ }^{3}$, Christian \\ Rammer $^{4}$
}

\begin{abstract}
:
Based on representative firm-level data for the three countries Austria, Germany, and Switzerland, we investigate the effects of energy-related regulations, taxes, voluntary agreements, and subsidies on the creation of green energy products, and analyze through which channels policy affects green product innovation and which factors mediate the observed effects. Policy may affect green product innovation by directly stimulating the supply of green products/services, or more indirectly by stimulating the demand for green products/services. Our data set allows us to distinguish between the two channels, which improves our understanding of the frequently observed positive net effect of policies. Controlling for the demand-side effect, taxes and regulations are negatively related with green product innovation. Hence, if taxes and regulation do not trigger additional demand, they decrease the propensity to innovate. These effects are ameliorated for technologically very advanced firms and for firms with a high level of financial awareness. Subsidies and (partly) voluntary agreements are positively related with green product innovation.
\end{abstract}

Keywords: Green innovation; product innovation; process innovation; policy; demand JEL classification: O30; O34; Q55.

\footnotetext{
${ }^{1}$ University of Jyväskylä, Finland; corresponding author: tobias.m.stucki@jyu.fi

${ }^{2}$ ETH Zurich, Swiss Economic Institute (KOF), Zurich, Switzerland.

${ }^{3}$ Austrian Institute of Economic Research (WIFO), Vienna, Austria.

${ }^{4}$ Center for European Studies (ZEW), Mannheim, Germany.
} 


\section{Introduction}

Even though green innovations are essential in order to address climate change (IPCC 2014), private firms are often not willing to invest in the creation of such technologies. Probably the main reason for this is that the greatest benefits from green products/services are likely to be public rather than private. Therefore, potential customers' willingness to pay for these products/services is low, which normally results in lower or even negative returns compared to traditional innovation activities (Marin 2014, Soltmann et al. 2015). As a consequence, policy intervention is required to stimulate the creation of green products/services. In-depth knowledge about the meaning of different policy instruments for green product innovation is thus crucial.

Hence, it is not surprising that there are many studies analyzing how policies affect green innovation. In general, they confirm the expected positive relationship between policy and green innovation (for a review of this literature see Ambec et al. 2013 or Popp et al. 2010). In the study at hand, we present a differentiated perspective looking in greater detail at the mechanisms through which policy affects green innovation.

First, most existing studies define green innovation activities broadly. However, a clear distinction between product and process innovation is crucial, since policies are likely to show different effects on the two types of innovation. Although the focus of this study is on green product innovation, we also investigate - in an extension of the basic analysis - whether policies show significantly different effects on product than on process innovation. Moreover, as green process innovation is not cost-free, we also test a potential moderating effect of green process innovation on the effect of policy on green product innovation.

Second, policy may directly induce green product innovation by affecting the supply of green products/services, or more indirectly by stimulating the demand for green products/services. In this study, we capture a potential demand-side effect of the analyzed policy measures on innovation, which allows us to differentiate the two channels through which policy affects innovation. Most of 
the existing studies measure a mixed policy effect comprising demand- and supply-side factors. We argue that the direct (supply-side) policy effects are significantly smaller than the mixed policy effects.

Third, most existing studies use patent data in order to identify green innovation activities, limiting the investigation to a rather small group of mainly highly innovative firms (Griliches 1990). Since technologically more advanced firms are more likely to respond with innovation to cost increasing policy measures, such as regulations and taxes, the observed effects tend to be larger for such leading innovators than for innovation laggards, referring to firms that normally are excluded from patent statistics. In this study, we capture green product innovation activity more broadly and test a potential moderating effect of the firms' innovation potential.

Concretely, we investigate the effect of different policy instruments on the creation of green products/services based on a representative firm-level survey simultaneously conducted in 2015 in Austria, Germany and Switzerland. Hence, the focus of this paper is on green product innovation, i.e. the creation of new green products/services or services for end-user, and not on process innovations, referring to the adoption of green products/services to improve firms' own production processes. The survey considered innovation activities in the field of green energy technologies, which refers to energy saving technologies and technologies for the generation of energy from renewable sources. Besides information on the firms' innovation decision, the dataset also contains information on the relevance of energy-related taxes, subsidies, regulations and voluntary agreements for the firms. This allows us to investigate how a firm's green (energy-related) policy exposure affects its green (energy) product innovation activities.

The availability of information for different policy measures allows us to compare their effects with each other. Another important advantage of the dataset is that it includes firm-level information on a broad set of other drivers of green innovation activities, enabling us to test different potential moderators of the effect of policy on green product innovation. This is important because it is not the goal of this paper to precisely identify the effect of a single policy shock in a 
certain country at a certain point in time, but to improve our understanding through which channels policy affects green product innovation and which factors mediate the observed effects. Finally, the dataset also allows us to compare the effect of policy across the three countries, which is important as the characteristics of the environment (e.g., the firms' policy affinity) may moderate the effect of different policy types on innovation activities.

The empirical analysis indicates that existing studies are likely to overestimate the direct (supply-side) effects of policies on green product innovation. While public subsides show the expected positive effect on product innovation, no significant effect is observed for voluntary agreements, and the (supply-side) effects of taxes and regulations on green product innovation are even negative in our setting. These findings withstand several robustness tests, e.g., they are not driven by a selection of specific firms that have few opportunities for green innovation, and the results do not significantly differ across the three countries considered in our data. In several extensions of the baseline model, we find that the negative policy effects are significantly ameliorated for firms operating at the technological frontier (leading innovators) and firms with a high financial awareness, which offers plausible explanations for the rather unexpected negative effects of taxes and regulations on green product innovation.

\section{Conceptual background and hypotheses}

\section{The effect of policy on green product innovation}

Our current understanding of how policy affects green innovation has strongly been influenced by the article of Porter and van der Linde (1995). They argued that firms face market imperfections, such as asymmetric information, organizational inertia or control problems (Rubashkina et al. 2015), that make it hardly possible for them to understand the full costs of incomplete utilization of resources and thus to identify all profitable opportunities for new products or processes. Policies help to overcome some of these market failure by signaling firms about likely resource inefficiencies and pursing otherwise neglected technological improvements. In what Jaffe and 
Palmer (1997) later defined as the "weak" version of the porter hypothesis, Porter and van der Linde thus concluded that "properly designed environmental standards can trigger innovation" (Porter and van der Linde 1995, p. 98). While Porter and van der Linde (1995) focus in their analysis on regulation, their hypothesis can be extended to other policy types as well (see Lanoie et al. 2011). Hence, we would expect that not only energy related regulations, but also subsidies, taxes and voluntary agreements push green innovation.

There are many studies that analyze the impact of regulation on green innovation, and most of them find the expected positive link, although the strength of the link varies (see Ambec et al. 2013 for a review of this literature). Studies that analyze the impact of other policy types on green innovation are somewhat rarer, but most of them also identify a positive effect (e.g., Lanoie et al. 2011, Ley at al. 2016, Veugelers 2012).

The green policy literature lacks a clear distinction between product and process innovation. Porter and van der Linde (1995) use the term innovation very broadly, which includes innovation referring to a "product's or service's design, the segment it serves, how it is produced, how it is marketed and how it is supported" (Porter and van der Linde 1995, p. 98). Similar to Porter and van der Linde most other studies that analyze the relationship between policy and innovation do not specify which type of innovation is really considered. Hence, we would expect that the discussion above holds for innovation in general, and we thus formulate the following hypothesis for green product innovation, i.e. the creation of new products or services for end-user:

Hypothesis 1: Taxes, regulations, voluntary agreements and subsidies positively affect a firm's green product innovation activities.

\section{Demand-side vs. supply-side effect of policies}

Following the policy-induced innovation view, investments are directed to factors that become more expensive (e.g. energy). Hence, green policy leads to investments in ways to meet the policy- 
induced constraint at lower cost (Jaffe and Palmer 1997), i.e. green investments, which in turn also increase the demand for new green products/services developed elsewhere. ${ }^{1}$ And it is widely accepted that market demand is an important driver of product innovation in general (Kleinknecht and Verspagen 1990, Schmookler 1966), and demand is also found to be important for the creation of environmental innovation (Horbach 2008).

Hence, policy can affect green product innovation by directly stimulating the supply of green product innovation (supply-side effect), or indirectly by increasing demand for new green products developed elsewhere (demand-side effect; see Figure 1).

Based on the discussion above, policy should positively affect demand for green products, which in turn should stimulate green product innovation. Hence, the demand-side effect of policy should be positive. Most existing studies do not capture potential demand-side effects and thus identify a mixture of the demand-side and the supply-side effect (e.g., Johnstone et al. 2012, Lanoie et al. 2011, Veugelers 2012). As the direction of the demand-side effect of policies should be positive, we expect the policy effects to be significantly lower when potential positive demandside effects are captured, i.e., that the direct (supply-side) policy effects are significantly smaller than the mixed policy effects.

Hypothesis 2: By capturing the demand-side effect of policies, the effect of taxes, regulations, voluntary agreements and subsidies on green product innovation is reduced, i.e. we expect their impact to be smaller or even negative.

The cost aspect of policies

\footnotetext{
${ }^{1}$ Of course, firms/end-user can develop these technologies in-house. However, this is seldom the case. The survey among Swiss, German, and Austrian firms showed that around 8\% of green technology adopting firms (partly) developed these technologies in-house. The in-house development of technologies requires a sufficient large in-house knowledge base and an in-depth knowledge about the whole production process (Porter and van der Linde 1995).
} 
In the literature, policy instruments are often grouped into the two broad categories of demandpull and supply-push policies (e.g., Hoppmann et al. 2013; Horbach et al. 2012; Nemet 2009; Peters et al. 2012; Rennings 2000). Energy taxes and regulations are typically seen as demand-pull policy, (R\&D) subsidies as technology-push policy. According to this literature, we would expect that the main effects of regulations and taxes will go through demand. Therefore, the supply-side effect of these policies should be small. But what about the direction of the direct supply-side effect of these policies? In contrast to the policy-induced innovation view following Porter and van der Linde (1995), the direct (supply-side) effect of regulations and taxes may even be negative, as they directly cause costs in the companies. Regulations tend to increase the costs of the production processes (Simpson and Bradford 1996, Mohr and Saha 2008), since formerly costless negative externalities have to be priced in. This will increase the lack of internally available funds and even might require a shift of internal funds away from more profitable projects (Gray and Shadbegian 1998) in order to comply with the policy requirements. Since innovation activities are predominantly financed by firm-internal funds (Hall 2002, Hall and Lerner 2010), additional production costs will lower internally available funds, and, consequently, are likely to constrain the financial opportunities to invest in product innovation activities. Following this view, policies such as regulations and taxes are likely to have a negative direct effect on the supply of green product innovation. However, if policies do not constrain the financial situation of a firm, as it is the case with public subsidies, the direct effect on green product innovation should be positive.

Hypothesis 3: While the supply-side effects of taxes and regulations on green product innovation should be negative, positive supply-side effects are expected for subsidies.

\section{Description of the data}

The empirical testing of the hypotheses is based on firm-level data that were collected in the course of a survey on the "creation and adoption of green energy technologies" carried out in 2015. In this 
survey "green energy technology" refers to energy saving technology and technology for the generation of energy from renewable sources. In order to test the robustness of our findings for different countries, the survey was simultaneously collected in the three countries Austria, Germany and Switzerland. ${ }^{2}$ To obtain representative results, the survey was based on representative firm samples i.e., the WIFO Enterprise Panel for Austria, the ZEW Enterprise Panel for Germany, and the KOF Enterprise Panel for Switzerland. Because most firms belonging to the service sector are rather unlikely to have generated green energy technologies for end-users (i.e., product innovation), the final samples used for this survey were restricted to the whole manufacturing sector (excluding the food industry, textile and cloth industry, printing, pharmaceuticals, and 'other manufacturing') and firms belonging to the two service industries 'information technology services' and 'technical services'. ${ }^{3}$ Concretely the survey was sent to 2,129 Austrian firms, 2,780 German firms and 2,870 Swiss firms. To maximize the credibility of the information, the survey was sent to the executive board of the companies. Valid information was received for 210 Austrian firms (response rate: 10\%), 1,056 German firms (37\%), and 921 Swiss firms (32\%). Given the very demanding questionnaire the response rates for Germany and Switzerland are satisfying, but disappointing for Austria. However, a comprehensive recall action in all three countries ensures that a sufficient large number of answers was received for all three counties, covering all industries and all firm size classes according to the underlying sampling schemes. ${ }^{4}$

\footnotetext{
${ }^{2}$ Austria is a small, technologically advanced country that shows a strong affinity to regulation and is part of the European Union. Switzerland is also technologically advanced, but shows reluctance to regulation. Germany has a large domestic market, is technologically advanced and shows a considerable amount of green (and energy-related) regulation activities. As a consequence it is interesting to compare the different policy regimes against the background of different industry structures and regulation affinity. Also the importance of large domestic markets for policy measures can be better taken into consideration in comparative studies. Moreover, our policy analysis can be more profound if it is based on more stable econometric models due to a greater number of observations.

${ }^{3}$ In a previous survey Arvanitis and Ley (2010) found that all other industries are unlikely to create themselves new green energy technologies or services for end-user, but primarily adopt green energy technologies developed by other firms (or create green products/services not directly related to energy, such as technologies to reduce water pollution). In order to reduce confusion, all other industries thus received only questions referring to the adoption of green products/services (i.e., process innovation).

${ }^{4}$ See Arvanitis et al. (2016) for a detailed sample information.
} 
Due to missing values for some model variables, our final estimation sample includes 1,987 observations; $48 \%$ of them are German firms, 44\% Swiss firms and 8\% Austrian firms. On average, the firms in our sample have 276 employees (median: 43 employees), whereupon $87 \%$ are SMEs with less than 250 employees. $72 \%$ of the firms belong to the manufacturing sector, $21 \%$ to the service sector and only $7 \%$ to the construction sector. ${ }^{5}$

Besides questions on some basic firm characteristics (sales, exports, employment, investment and employees' education), the survey included questions on energy related adoption and product innovation activities as well as on obstacles of such activities. Descriptive statistics for all model variables based on the estimation sample are presented in Table A.1 in the appendix; the correlation matrix is shown in Table A.2.

Related to the Communication Innovation Survey for innovation activities in general, the information on green energy innovation activities is based on questions that directly ask whether the firms created green energy technologies for end-user. In order to capture green energy innovation properly, a clear definition was used comprising energy-saving technology applications in (1) production, (2) information and communication technologies, (3) transport, (4) building and heating, and green energy-generating technologies from renewable sources. Moreover, as the focus is on innovations that have a clear environmental impact, the definition was restricted to product innovations which have already been introduced by the companies on the market.

$14 \%$ of the firms in our sample created green energy technologies or services for end-user, i.e. had green energy product innovation, and the green products/services add up to $13 \%$ of the green innovators' total sales, on average.

\footnotetext{
${ }^{5}$ Concretely, $12 \%$ of the firms are in the 'Basic Metals' industry, $11 \%$ in the 'Electronic and Optical Products' industry, $11 \%$ in the 'Machinery and Equipment' industry, $11 \%$ in the 'Technical Commercial Services' industry, 6\% in the 'Chemical' industry, 6\% in the 'Electrical Equipment' industry, 6\% in the 'Information Technology' industry, and 5\% in the 'Rubber/Plastics' industry. All other industries account for less than 5\% of the companies included in the final sample.
} 
The effect of different energy-related policy types, actually, should be investigated with "objective" data. ${ }^{6}$ However, this is hardly possible at the firm level primarily for two reasons. First, to get a complete picture, all relevant policies would need to be identified, which is hardly possible as they can be firm/sector- and technology- specific. Hence, it is for example difficult to generate a measure that captures the effect of all energy-related subsidies within a country. Also, it does not make sense to focus on public R\&D information for a country like Switzerland, where direct innovation subsidies are of low importance. Second, besides the identification of relevant policies, also the stringency of single policies, i.e. how strong a firm is affected, has to be identified, which is a difficult task (Levinson 2008, Shadbegian and Wolverton 2010, Xing and Kolstad 2002). The difficulty arises from the fact that different policies typically cover different firms, policies may exist at multiple levels (e.g. federal and local), and monitoring and enforcement are imperfect (Millimet and Roy 2015).

In other words, by using "objective" policy data, the researcher has to select certain policy measures, which probably do not represent the true policy mix of the individual firm. To overcome this problem, we do not make this selection of policies ourselves, but included a specific set of questions in the survey, where the firms themselves assessed the relevance of different energyrelated policy types for their activities (for a related procedure see, e.g., Johnstone et al. 2012, Lanoie et al. 2011, Stucki and Woerter 2016, Veugelers 2012). As these questions were typically filled by the management of the companies, the responses should give a relatively good picture of the firms' overall energy-related policy exposure. The relevance of the different policy types has been assessed by the firms on a three-point Likert scale. A first set of questions refers to four categories of energy-related policies, i.e. energy taxes, regulations, subsidies, and voluntary agreements. Another question refers to the importance of demand for green energy products.

\footnotetext{
6 "Objective" data is a misleading term. Very often, it just expresses insufficient knowledge about the data collection procedure. For instance, value added statistics of different countries are based very often on survey data of a sample of firms. Official figures on capital stocks are reflecting assumption about capital aggregation, devaluation rates, etc. In many cases the process of data generation/collection is not known or discussed. In contrast, we collected the data used in the study at hand; we know the sample, the questions, and potential pitfalls.
} 
Of course, the use of subjective survey data has also disadvantages. Probably the main concern in the empirical economic literature refers to endogeneity, as policy measures that are based on self-assessments may share systematic factors with the firms' green innovation activity (see Bertrand and Mullainathan 2001). ${ }^{7}$ In most existing studies using self-reported policy measures, the policy information comes from questions that ask firms directly to assess the importance of different policies as drivers for their green innovation activities (e.g., studies based on Community Innovation Survey). Compared to these studies, we ask the policy questions in a separate section in the beginning of the survey with no link to the section referring to the firms' green energy innovation activities. Hence, we reduce a potential assessment bias by avoiding a direct link between the policy exposure and the firms' innovation behavior.

\section{Empirical framework}

The firms' share of green energy technologies in total sales is used to measure green product innovation intensity in our baseline specification, which is a continuous variable ranging from 0 to 100 (see Table 1 for definition of all model variables). In order to deal with the presence of many firms that did not have green product innovation at all, we estimate Tobit regressions.

In a first step, the policy variables are directly included in the model. However, as these are ordinal variables, this may be problematic. In alternative regressions presented in Table A.3 in the appendix, we thus also present results that are based on binary variables.

To reduce a potential endogeneity problem due to omitted variables, we control for a broad set of observables affecting the firms' innovation activities in our estimations. Following the Schumpeterian tradition, we control for appropriability of research results, firm size, competition,

\footnotetext{
${ }^{7}$ However, we must be aware that using "objective" policy information would not solve a potential endogeneity problem. Even if an accurate "objective" measure of energy-related policy is available, it may be endogenous as it may be correlated with unobserved determinants of location choice such as tax breaks or other firm-specific treatments, the provision of other public goods in addition to environmental quality (e.g. infrastructure), agglomeration, the stringency of other regulations such as occupational safety standards, corruption, local political activism, political institutions, etc. (Millimet and Roy 2015). As the survey includes information on a broad set of observables that typically affect a firm's green innovation activity, we are probably even in a better position to tackle the problem.
} 
demand, industry affiliation, and the technological potential (see Cohen 2010 for a review of the literature). Moreover, in order to be able to identify direct policy effects on green product innovation activities, we have to control for the firms' green innovation affinity. One could for example argue that energy related policies primarily affect energy intensive firms, which in turn are often in industries that typically have few opportunities to create themselves green products for end-user. To capture such indirect effects, we add specific controls for the firms' green process innovation activities, and a measure for whether the firms' products are suited for green product innovation or not (in addition, we also control in detail for the firms' industry affiliation).

As we lack true dynamics in our data, we should nevertheless be careful in interpreting the causality of the policy effects. Instead, the policy and innovation variables are considered as structural variables and the estimated coefficients are interpreted as partial correlations, which still allows a characterization of a political environment that is green innovation friendly. We have to keep in mind that it is not the goal of this paper to precisely identify the effect of a single policy shock in a certain country at a certain point in time, but to test different moderators through which policy affects green product innovation.

\section{Estimation results}

\section{Policy effects on green energy product innovation}

The effect of the different policy variables on green product innovation is presented in Table 2 . Columns 1 to 8 present estimation results that test the effect of the different policy variables individually (columns with even numbers additionally include a control for demand). In line with hypothesis 1 , we observe a significant positive effect of subsidies on product innovation (see columns 5 and 6). However, unlike expected significant negative effects are observed for taxes (columns 1,2) and regulations (column 4). The effect of voluntary agreements seems to be moderate, but at least not significantly negative (columns 7 and 8). 
In order to reduce a potential omitted variable bias, estimation results that include all policy variables simultaneously are presented in column 9. These results largely confirm previous findings. The only exception is the regulation effect that gets somewhat smaller and now is not significantly negative anymore.

A first explanation for the negative policy effects can be found in the models that control for the indirect effect of demand as described in hypotheses 2 and 3. To be able to identify the direct (supply-side) effect of the different policy types on product innovation, we have to capture their indirect demand-side effect. We do this by controlling for the effect of demand for green products (see columns with even numbers). Demand shows the expected positive effect on product innovation. Because the policy variables also capture part of this positive demand effect, i.e. we measure a mixed policy effect comprising demand- and supply-side effect, the policy effects significantly decrease and become negative or more negative when we add a control for demand. Hence, as predicted in hypothesis 2, controlling for the demand-side effect reduces the effect of taxes, regulations, voluntary agreements and subsidies on green product innovation, i.e., their effect become smaller in size or even negative. The effect of controlling for demand is quite substantial. While the effect of regulations and voluntary agreements switch their signs, the positive effect of subsidies is reduced by nearly two-thirds. As predicted in hypothesis 3 , a positive supply-side is observed for subsidies, a negative supply-side effect is observed for taxes. The supply-side effects of regulations tend to be insignificant, but point in the expected direction. No significant effect can be identified for voluntary agreements either.

In Table A.3, the relevance of the policy stringency is analyzed for the different policy measures (based on the full model that also controls for demand). In general, the effects seem to accentuate with increasing relevance of the policy instruments. The effects, however, significantly differ only for taxes and demand. ${ }^{8}$ While the negative effect of taxes is primarily driven by taxes

\footnotetext{
${ }^{8} \mathrm{P}$-values of tests on equality of coefficients for medium and high relevance: taxes 0.001 ; regulations 0.282 ; subsidies 0.791 ; voluntary agreements 0.501 ; demand 0.000
} 
that heavily affect firm activities, the effect of demand is significantly positive for moderate and high demand.

The effects of the different policy types on product innovation are very robust and withstand several robustness tests. First, they hold for alternative estimation procedures and dependent variables (see Table A.4). Switching to a linear regression that does not control for the large number of firms without innovation activities does not affect the results (column 1). When focusing on innovation propensity rather than intensity (column 2), the effect of taxes gets somewhat smaller compared to regulations, which shows a significantly negative effect in the propensity equation. However, the general pattern is the same as before: negative effects for taxes and regulations, positive effects for subsidies and demand, and no effect for voluntary agreements. Moreover, the effects look very similar when we analyze the effects on green R\&D propensity (column 3). While the explanatory power of this model is somewhat smaller, the size and direction of the different policy effects is very similar to those observed in the model that analyzes green innovation propensity.

Second, the results hold for different sub-samples of firms. A possible explanation for the negative policy effects could be that taxes and regulations primarily affect firms that have few opportunities for green product innovation. However, such a problem should be significantly reduced by the inclusion of several controls for the firms green innovation affinity. To further test the robustness of our results, we present in Table A.5 regressions that do not control only for the firms green innovation affinity, but also restrict the estimation sample to firms that (a) at least were discussing about the creation of green products/services in their firms ${ }^{9}$, or (b) believe that their products/services are suited for green product innovation ${ }^{10}$. Hence, firms that are affected by

\footnotetext{
${ }^{9}$ This information comes from a question that asked firms whether they never were discussing about the creation of green energy products within their firms. If firms answered this question with yes, they were excluded.

${ }^{10}$ This information is based on a question that asked firms to assess whether their products/services are not suited for green product innovation (four-level ordinary variable; level 1: 'fully disagree'; level 4: 'fully agree'). Firms with a value of 4 were excluded from the regression.
} 
policy, but have few green innovation opportunities drop out in both settings. The results in Table A.5 show that our previous findings also hold when we impose such sample restrictions.

Third, we test the robustness of our results for the different countries. Based on separate regressions for the three countries, we cannot identify large differences concerning the policy effects in Austria, Germany and Switzerland, respectively (see Table A.6). The only exception are taxes that show a more negative effect in Germany than in the other two countries (see column 2). This larger effect of taxes seem to be driven by the fact that taxes are more pronounced in Germany $^{11}$; as we have seen in Table A.3, the negative effect of taxes on product innovation is primarily driven by taxes that heavily affect firm activities (as is shown in column 4 of Table A.6, this finding also holds for Germany).

With respect to the control variables, we observe that primarily the firms' general innovation capabilities affect green product innovation activities; positive effects are observed for both the qualification level of the employees and the firms R\&D propensity. Moreover, we identify a positive effect of competition. As expected, the firms' green innovation affinity seems to be relevant as well; the firms' green process innovation intensity and the suitability of their products for green product innovation both show statistically significant effects.

In what follows, we try to find explanations for the unexpected negative effects of taxes and regulations on product innovation.

\section{What drives the negative effect of taxes on product innovation?}

Taxes place constraints on the profit opportunities of firms, e.g., because they force the firms to pay $\mathrm{CO}_{2}$ taxes. Profit maximizing firms subject to such constraints will be more likely to invest in ways to meet the constraint at lower cost (Jaffe and Palmer 1997). As product innovations are sold to end-users, they primarily affect the customers' production process. The production processes of

\footnotetext{
${ }^{11}$ Based on Chi-square test, we find that high taxes are observed significantly more often in Germany than in the other two countries (p-value: 0.000). No differences, however, are observed for moderate taxes (p-value: 0.945).
} 
the innovating firms, however, are primarily affected by process innovations. Hence, probably taxes primarily stimulate the firms' process innovation rather than their product innovation activities.

Differences in the effects of policy on green product and process innovation are tested in Table 3. While we observe a negative effect of taxes on green product innovation, we indeed observe a positive effect on green process innovation, which is in line with the general predictions of Porter and van der Linde (1995). Hence, taxes seem to affect the firms green product and process innovation activities differently. The differences between product and process innovation are less pronounced for all other policy types. The effect of regulations also switches sign but is statistically insignificant for both types of innovation. The effects of public subsidies and voluntary agreements have positive signs for both product and process innovation. Interestingly, however, not only taxes, but also regulations, subsidies and voluntary agreements show larger effects on process innovation than on product innovation. ${ }^{12}$

The positive effect of taxes on process innovation may also be part of the explanation of its negative effect on product innovation. Process innovation is not cost-free. In our sample, about two-third of the firms with green energy product innovation also have green energy process innovation. Moreover, the median product innovator is relatively small: it has 70 employees, its annual total $R \& D$ spending is $€ 150,000$, whereof $€ 50,000$ are spent for green energy product innovation. Compared with these figures, the $€ 28,000$ annual spending for green process innovation looks quite substantial. Hence, if a policy stimulates a firm's green process innovation activities, costs are generated. These policy-induced investments may directly have consequences

\footnotetext{
12 The magnitude of the effect of subsidies on process innovation is twice as large compared with product innovation (p-value for test on equality of coefficients: 0.081). Moreover, we observe larger effects of taxes and regulations on green process innovation than on green product innovation ( $p$-values for tests on equality of coefficients: 0.000 and 0.057 , respectively). The difference in the effect of voluntary agreements is not statistically significant ( $p$-value: 0.202). The effect of demand, however, is much smaller for process than for product innovation (p-value: 0.000$)$. These tests are based on simultaneous regressions of the two models. In order to allow convergence, these tests are based on models that control only for sector affiliation, and not for industry affiliation as in the other models. Moreover, the product innovation model did not include a control for process innovation, as potential correlation between the two types of innovation is captured by the simultaneous regression of the two models.
} 
for product innovation. If a firm has to invest heavily in green process innovation, the firm's financial resources for product innovation may decrease, which would negatively affect the firm's product innovation activities. Hence, we expect a moderating effect of a firm's process innovation activities on the effect of taxes on green product innovation, i.e., due to more limited financial resources the effect of taxes on product innovation is expected to be significantly smaller for firms with high investments in process innovation than for firms with low investments in process innovation.

In order to test this prediction, we add in Table 4 an interaction term between a firm's process innovation intensity and its policy affectedness to our baseline model, which simultaneously controls for all different policy effects. As predicted, we observe a moderating effect of process innovation for taxes identified by the significant negative sign of the interaction term between taxes and process innovation. Moreover, once we control for this moderating effect, the negative effect of taxes on product innovation is not statistically significant anymore (see column 1 and 6) and even becomes positive when we test the effect of taxes individually (see column 2). In sum, these results indicate that the main driver of the negative effect of taxes on product innovation are taxinduced process innovations that reduce a firm's innovation capital and thus negatively affect product innovation activities; if a firm does not have intensive process innovation activities, the effect of taxes is not statistically significant negative. No moderating effect of process innovation is detected for regulations (column 3), subsidies (column 4) and voluntary agreements (column 5), which is not surprising, as we do not observe opposite effects of these policies on process and product innovation.

Besides the negative interaction effect, we still observe a positive direct effect of green process innovation on green product innovation. This result indicates that green product and process innovations per se are complements. However, if process innovation is induced by policy, which is measured by the interaction term between process innovation and policy measures, the total effect of taxes on green product innovation decreases and becomes statistically significant 
negative. Moreover, as the positive direct effect of green process innovation is much larger in magnitude than the negative indirect effect via policy, the total effect of green process innovation on green product innovation is still positive.

\section{What drives the negative effect of regulations on product innovation?}

The negative effect of regulations may be driven by compliance costs that often occur because regulations introduce high complexity into business operations. Firms are faced with rapidly evolving and increasingly severe and complex environmental regulations (Buysse and Verbeke 2003). "In 1970 there were about 2,000 federal, state, and local environmental rules and regulations

in the United States; today there are more than 100,000. The code of Federal Regulations for protection of the environment currently exceeds the size of the U.S. Tax Code. Environmental regulations are listed in over 789 parts of the Code of Federal Regulations." (Berry and Rondinelli 1998, p.39).

The complexity of regulation, however, is expected to decrease with a firm's regulation experience. Dean and Brown (1995) for example predict that "the more a firm deals with environmental regulatory agencies and has to perform pollution control activities, the more the firm learns (1) which regulations and agencies apply to its activities and how to effectively handle them, (2) which pollution abatement technologies apply to its production processes and how to use them effectively, and (3) how to best modify its organizational and administrative processes to carry out these tasks" (Dean and Brown 1995, p.292). In sum, regulation experience is thus expected to reduce a firm's compliance costs. This should not hold only for regulation experience, but also for innovation experience, or more generally, the firms' innovation potential. The larger a firm's green innovation potential, the easier it will be to adapt its products to new regulations or to detect completely new innovation opportunities. In line with this prediction, Amable et al. (2009) find for innovation in general that the impact of regulation on innovation, even when it is negative 
if a firm is far from the frontier, changes sign and is increasingly positive as one moves closer to the technological frontier.

Hence, in order to test whether complexity drives the negative effect of regulations on product innovations, we analyze potential differences in the effect of regulations on the green product innovation activities of leading innovators and laggards. While innovation laggards are expected to develop primarily products that are new to the firm, innovation leaders are expected to create primarily innovations that are new to the market. Accordingly, we would expect larger effects of regulations on the creation of new to the market innovations than on the creation of products that are only new to the firm.

Regressions where we split product innovations by its level of innovativeness into these two categories are presented in Table 5. The results largely confirm our predictions. As for product innovation in general, we observe a statistically significant negative effect of regulations on new to the firm product innovation (columns 3, 5 and 11). Regulations, however, positively affect new to the market product innovation, even though the effect is statistically significant only when we do not control for demand (column 6).

Beside regulations, taxes also do not show a significant negative effect on new to the market innovation, which may be due to the fact that especially in the short run much innovation experience is required to react quickly to tax changes. The difference in the effects between new to the firm and new to the market innovation, however, is more accentuated for regulations than for taxes ${ }^{13}$, which emphasizes the complexity of regulations. For subsidies, the effect even shows in the other direction, i.e. the positive effect of subsidies on new to the market innovation is somewhat larger than the effect on new to the firm innovation, ${ }^{14}$ which indicates that primarily

\footnotetext{
${ }^{13}$ P-value for test on equality of coefficients for regulations: 0.011 for columns 3 and 4 and 0.021 for columns 11 and 12. The effect of taxes does not significantly differ for the two innovation types ( $p$-values for tests on equality of coefficients: 0.187 for columns 1 and 2 and 0.814 for columns 11 and 12).

${ }^{14}$ However, the difference is not statistically significant (p-values for tests on equality of coefficients: 0.142 for columns 7 and 8 and 0.143 for columns 11 and 12).
} 
high-end research profits from public subsidies. The effect of voluntary agreements differs only slightly for the two types of innovation. ${ }^{15}$

The results look very similar, when we use the firms' green R\&D activities as measure for their green innovation potential. As for innovations that are new to the market, the effect of regulations is positive and statistically significant when we restrict our sample to firms with green R\&D activities (see Table A.7). Here, again we see that technologically advanced firms might positively respond to regulation with new technological developments that is likely to be no option for R\&D inactive firms.

\section{Additional test for the relevance of financial resources}

In sum, the previous findings indicate that the negative effects of regulations and taxes on product innovation is driven by a reduction in financial resources-either due to high compliance costs or more indirectly via induced process innovation-that could alternatively be used for product innovation activities. In order to test the relevance of this financial channel more directly, we present in Table 6 regressions that include a specific measure for the firms' financial awareness. ${ }^{16}$ If the reduced financial resources are really responsible for the negative effect of taxes and regulations on green product innovation, firms with high financial awareness should show more positive policy effects, because they can handle policy-induced financial restrictions easier. And in fact, we detect for taxes and regulations the expected positive interaction effects with financial awareness. In line with previous findings, no significant interaction effect is found for subsidies and voluntary agreements. We thus conclude that financial awareness indeed seem to moderate the negative effects of regulations and taxes on green product innovation.

\footnotetext{
15 The effect of voluntary agreements does not significantly differ for the two innovation types (p-values for tests on equality of coefficients: 0.945 for columns 9 and 10 and 0.363 for columns 11 and 12).

16 The measure for financial awareness is based on a question that asks the firms to assess the relevance of lack of financial resources as an obstacle for their green product innovation activities (see Table 1 for exact definition). This variable can be interpreted as the firms' financial awareness, as particularly firms that are heavily dependent on financial resources should be aware of this restraint (see, e.g., D'Este et al., 2012 for a similar interpretation of related variables). In line with this interpretation, we observe a positive and not a negative correlation between product innovation and financial awareness (see Table 6).
} 


\section{Discussion}

While the existing literature generally predicts a positive effect of policy on (product) innovation, we find such positive effects only for subsidies and (at least partially) voluntary agreements. Regulations and taxes, however, negatively affect product innovation. These results withstand several robustness tests and contrasts existing studies that observe a positive relationship between policy and product innovation (for a review of the literature see Ambec et al. 2013 or Popp et al. 2010). What might drive the different results?

We have four different explanations. First, most studies that analyze the relationship between policy and innovation do not specify which type of innovation really is considered (see, e.g., Porter and van der Linde 1995). In many studies the type of innovation that is investigated, is (partly) determined by the type of applied data. Many studies use patent data or R\&D data to measure innovation (see, e.g., Aghion et al. 2016, Jaffe and Palmer 1997, Johnstone et al. 2010, Ley et al. 2016). While this allows collecting comparable data for different countries over a long time period, it makes it hardly possible to identify whether the innovation activities refer to process or product innovation. Even though one could argue that primarily product innovations will be patented, the identified innovation effects will be partially mixed. As we have shown in the study at hand, the effects are likely to differ for the two innovation types; in general, we expect to observe more positive effects for process innovation than for product innovation. Existing studies based on patent and $R \& D$ data are thus expected to overestimate the policy effects on product innovation.

Second, the use of patent data and to a lesser extend also R\&D data to measure innovation activities induces another problem, as this data captures only very specific types of innovation, limiting the analysis to a rather small group of mainly highly innovative firms (Griliches 1990). In

our data set, only $57 \%$ of the firms with green energy product innovation also have green R\&D 
activities; for sure, the fraction is significantly lower for patenting firms. ${ }^{17}$ In general, patenting firms are expected to operate at the technological front (leading innovators). As we have shown, the effect of taxes and regulations tend to be more negative for innovation laggards than for leading innovators, either identified based on the firms green R\&D activities or the depth of their innovation output measured by commercialized products that are "new to the market". Hence, it is likely that existing studies based on patent data and R\&D data overestimate the effect of taxes and regulations on product innovation in general.

Third, studies that are based on survey data mostly use policy measures that come from questions that asked firms directly to assess the importance of different policies as drivers for their innovation activities (see, e.g., Horbach et al. 2012, Stucki and Woerter 2016, Veugelers 2012). As firms with few or no innovation activities are unlikely to answer that their innovation activities are heavily affected by policies, a non-negative relationship between the assessment and the firms' innovation activities is prefigured in the data.

Fourth, in contrast to most of the existing studies (e.g., Aghion et al. 2016, Johnstone et al. 2012, Lanoie et al. 2011), we can control for the demand-side effect of policies, which allows us to separate "supply-side" from "demand-side" driven policy effects. This is hardly possible in studies using data that is aggregated at the industry or country level, as the producers and the potential consumers at these aggregation levels often belong to the same observational unit (e.g. the country). In this study, we found that controlling for the demand-side effect significantly reduces the policy effect on innovation. Hence, the often observed mixed policy effect is likely to be larger than the direct (supply-side) effect of policy on innovation.

\footnotetext{
${ }^{17}$ Unfortunately, our survey does not include information regarding the firms patenting activities. However, according to the KOF Innovation Survey 2015, which captures traditional innovation activities in Switzerland, only $63 \%$ of the firms with product innovation had R\&D activities, and only $30 \%$ had patenting activities.
} 


\section{Conclusions and policy implications}

In this study, the relationship between policy and green product innovation is analyzed based on a unique data set that covers firm-level data for Austria, Germany and Switzerland. The cost perspective of policies is discussed in the neoclassical literature, but it has been nearly ignored in the empirical literature in the tradition of the Porter-hypotheses. This paper tries to unify both views in an empirical model that controls for the demand effects of policies and consequently highlighting the cost-related effects of policy measures for the firm. The main results can be summarized as follows. First, different policy instruments differently affect green product innovation. While we observe positive effects of subsidies, no effects are found for voluntary agreements, and even negative effects are detected for taxes and regulations. Second, the effects of most tested policy instruments differ for product and process innovation. In general, we find more positive effects of policies on process innovation than on product innovation. Third, the negative effect of regulations and taxes on green product innovation is mainly driven by a reduction in financial resources that can be used for product innovation, in the case of regulations due to high compliance costs or in the case of taxes more indirectly via induced process innovation. Fourth, the size of the policy effects largely depends on the firms' green innovation potential. Negative policy effects are observed only for typical innovators, but not for technological leaders. Fifth, capturing indirect demand effects significantly reduces the effect of policy on green product innovation.

The study shows that energy policies increase the costs for the economy, since financial means have to be shifted away from more profitable adventures to comply with regulations and/or taxes. This suggests a policy regime that considers supply-side as well as demand-side effects of new policies. Consequently, the cost related burden for the economy might turn into profitable business opportunities due to an advanced policy regime. This contrasting view reveals some important information for the effects of policies and it has some important implications for the design of new policies. First, in order to efficiently address climate change, the diffusion of green 
products/services is crucial. However, technologies can diffuse only if someone is willing to create them. As our results indicate that policies differently affect product and process innovation, an effective policy design is challenging. With respect to green product innovation, it is important to consider also the cost aspects of policy measures. There is a fine line when it comes to designing policy measures. If the policy measures is not stringent enough, it won't trigger demand for green products and thus limit additional innovation activities (Lanoie et al. 2011). However, if policy measures are very stringent, the costs of adapting the production process to the policy requirements are too demanding for companies, which then has a negative impact on green product innovation activities." Popp et al. (2010, p. 876) have formulated a basic rule that refers to this issue: "But, all else being equal, emissions of pollutants that are very costly to eliminate should be tolerated, because the marginal cost of reducing them is high." Second, more positive effects of taxes and regulation can be expected if firms operate at the technological front. Policies that support firms to accumulate technological know-how or to develop innovative technological solutions, essentially contribute to the effectiveness to demand-side related policies. Such promotion schemes are not necessarily limited to energy technologies alone, the promotion of innovation excellence in general creates positive spillovers for energy technologies if the promotion schemes are bottom-up and if there is a societal consensus that new technologies are an essential part of facing climate change successfully. Moreover, the results indicate that a reduction in the complexity of regulations is crucial in order to broadly stimulate product innovation and not affect only the innovation leaders.

Finally, these findings have clear implications for research as well. First, nowadays the term innovation is used broadly in the empirical and theoretical literature that analyses policy effects. Our findings, however, indicate that research should be more precise in their definition of what is considered as innovation, because the effects are likely to differ for different types of innovation. Second, while most existing studies do not adequately control for demand, the results indicate that controlling for demand is crucial in order to be able to identify direct (supply-side) effects of policies. 


\section{Funding:}

This paper was financially supported by the Swiss National Science Foundation (SNSF), National Research Program "Managing Energy Consumption” (NRP71) and the Austrian Science Fund (FWF).

\section{References}

Aghion, P., Dechezleprêtre, A., Hemous, D., Martin, R., \& Van Reenen, J. (2016). Carbon taxes, path dependency and directed technical change: evidence from the auto industry. Journal of Political Economy, 124(1), 1-51.

Amable, B., Demmou, L., \& Ledezma, I. (2009). Product market regulation, innovation, and distance to frontier. Industrial and Corporate Change, dtp037.

Ambec, S., Cohen, M. A., Elgie, S., \& Lanoie, P. (2013). The Porter hypothesis at 20: can environmental regulation enhance innovation and competitiveness?. Review of Environmental Economics and Policy, res016.

Arvanitis, S., \& Ley, M. (2010). Generierung und Übernahme von Energietechnologien und energiepolitische Förderung in der Schweiz (No. 18). KOF Studien.

Arvanitis, S., Peneder, M., Rammer, C., Spescha, A., Stucki, T., \& Woerter, M. (2016). Creation and Adoption of Energy-related Innovations-the Main Facts, KOF Studies, Vol. 77.

Berry, M. A., \& Rondinelli, D. A. (1998). Proactive corporate environmental management: A new industrial revolution. The Academy of Management Executive, 12(2), 38-50.

Bertrand, M., \& Mullainathan, S. (2001). Do people mean what they say? Implications for subjective survey data. The American Economic Review, 91(2), 67-72.

Buysse, K., \& Verbeke, A. (2003). Proactive environmental strategies: A stakeholder management perspective. Strategic management journal, 24(5), 453-470.

Cohen, W. M. (2010). Fifty years of empirical studies of innovative activity and performance. Handbook of the Economics of Innovation, 1, 129-213.

Dean, T. J., \& Brown, R. L. (1995). Pollution regulation as a barrier to new firm entry: Initial evidence and implications for future research. Academy of Management Journal, 38(1), 288303.

Griliches, Z. (1990). Patent Statistics as Economic Indicators: A Survey. Journal of Economic Literature, 28(4), 1661-1707.

Hall, B. (2002). The financing of Research and Development. Oxford Review of Economic Policy $18(1), 35-51$

Hall, B., \& Lerner J. (2010). The financing of R\&D and innovation, in: Hall, B., Rosenberg, N. (eds), The Handbook of the Economics of Innovation, Vol. 1, 609-639.

Hoppmann J., Peters M., Schneider M., Hoffmann V. (2013). The two faces of market supportHow deployment policies affect technological exploration and exploitation in the solar photovoltaic industry. Research policy, vol. 42(4), pp. 989-1003. 
Horbach, J. (2008). Determinants of environmental innovation - new evidence from German panel data sources. Research policy, 37(1), 163-173.

Horbach, J., Rammer, C., \& Rennings, K. (2012). Determinants of eco-innovations by type of environmental impact-The role of regulatory push/pull, technology push and market pull. Ecological economics, 78, 112-122.

IPCC (2014). Climate Change 2014: Synthesis Report. Contribution of Working Groups I, II and III to the Fifth Assessment Report of the Intergovernmental Panel on Climate Change.

Jaffe, A. B., \& Palmer, K. (1997). Environmental regulation and innovation: a panel data study. Review of economics and statistics, 79(4), 610-619.

Johnstone, N., Haščič, I., Poirier, J., Hemar, M., \& Michel, C. (2012). Environmental policy stringency and technological innovation: evidence from survey data and patent counts. Applied Economics, 44(17), 2157-2170.

Kleinknecht, A., \& Verspagen, B. (1990). Demand and innovation: Schmookler re-examined. Research policy, 19(4), 387-394.

Lanoie, P., Laurent-Lucchetti, J., Johnstone, N., \& Ambec, S. (2011). Environmental policy, innovation and performance: new insights on the Porter hypothesis. Journal of Economics \& Management Strategy, 20(3), 803-842.

Levinson A. (2008). Pollution haven hypothesis. New Palgrave Dictionary of Economics (2nd edn). Palgrave Macmillan: Basingstoke, UK.

Ley, M., Stucki, T., \& Woerter, M. (2016). The Impact of Energy Prices on Green Innovation. The Energy Journal, 37(1), 41-75.

Marin, G. (2014). Do eco-innovations harm productivity growth through crowding out? Results of an extended CDM model for Italy. Research Policy, 43(2), 301-317.

Millimet, D. L., \& Roy, J. (2015). Empirical tests of the pollution haven hypothesis when environmental regulation is endogenous. Journal of Applied Econometrics, 31(4), 652-677.

Mohr, R.D., and S. Saha (2008). Distribution of Environmental Costs and Benefits, Additional Distortions, and the Porter Hypothesis. Land Economics 84(4): 689-700.

Nemet, G. F. (2009). Demand-pull, technology-push, and government-led incentives for nonincremental technical change. Research Policy, 38(5), 700-709.

Peters, M., Schneider, M., Griesshaber, T., \& Hoffmann, V. H. (2012). The impact of technologypush and demand-pull policies on technical change-Does the locus of policies matter? Research Policy, 41(8), 1296-1308.

Popp, D., Newell, R. G., \& Jaffe, A. B. (2010). Energy, the environment, and technological change. Handbook of the Economics of Innovation, 2, 873-937.

Porter, M. E., \& van der Linde, C. (1995). Toward a new conception of the environmentcompetitiveness relationship. The journal of economic perspectives, 9(4), 97-118.

Rennings K. (2000). Redefining innovation - eco-innovation research and the contribution from ecological economics. Ecological Economics, vol. 32(2), pp. 319-332.

Rubashkina, Y., Galeotti, M., \& Verdolini, E. (2015). Environmental regulation and competitiveness: Empirical evidence on the porter hypothesis from european manufacturing sectors. Energy Policy, 83, 288-300.

Schmookler, J. (1966). Invention and Economic Growth, Harvard University Press, Cambridge.

Shadbegian, R. \& Wolverton, A. (2010). Location decisions of U.S. polluting plants: theory, empirical evidence, and consequences. International Review of Environmental and Resource Economics, 1, 1-49.

Simpson, R.D. \& Bradford, R.L. (1996). Taxing Variable Cost: Environmental Regulation as Industrial Policy. Journal of Environmental Economics and Management, 30, 282-300.

Soltmann, C., Stucki, T., \& Woerter, M. (2015). The Impact of Environmentally Friendly Innovations on Value Added. Environmental and Resource Economics, 62(3), 457-479.

Stucki, T., \& Woerter, M. (2016). Intra-firm diffusion of green energy technologies and the choice of policy instruments. Journal of Cleaner Production, forthcoming. 
Veugelers, R. (2012). Which policy instruments to induce clean innovating?. Research Policy, 41(10), 1770-1778.

Xing, Y. \& Kolstad, C. (2002). Do lax environmental regulations attract foreign investment? Environmental and Resource Economics, 21, 1-22. 
Figure 1: How policy is expected to affect green product innovation

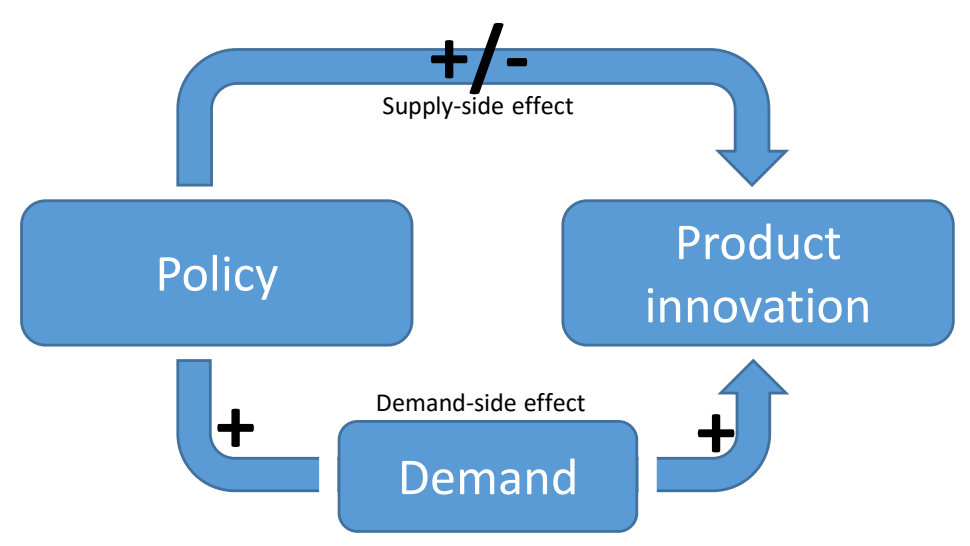


Table 1: Variable definition and measurement

Variable

Dependent variables

Green product innovation propensity

Green product innovation intensity

Green process innovation intensity

New to the market propensity

Green R\&D propensity

Independent variables

Export intensity

Share of high qualified employees

Foreign owned

Firm age

Competition intensity

R\&D propensity

Products not suited

Number of employees

Swiss firm; German firm

Taxes

Regulations

Voluntary agreements

Public subsidies

Demand

Industry controls

Financial awareness
Definition/measurement

Firm created new green energy products or services for end-users yes (value 1)/ no (value 0)

Share of sales of newly created green energy products/services in total sales, In Gross investments in green energy products/services (for the use within the firm) per employee, In

Firm created new green energy products or services that were new to the market yes (value 1)/ no (value 0)

Firm has domestic R\&D activities in the field of green energy technologies yes (value 1)/ no (value 0 )

Share of exports in total sales, In

Share of employees with a tertiary-level degree, In

Firm is owned by a foreign company yes (value 1 )/ no (value 0 )

Firm age in years, In

Firm has more than five competitors on their domestic and foreign prime market yes (value 1)/ no (value 0)

Firm has domestic R\&D activities yes (value 1)/ no (value 0 )

Green energy innovation is hampered by the fact that existing products/ services are not well suited for this type of innovation (four-level ordinary variable; level 1: 'low relevance'; level 4: 'high relevance')

Number of employees measured in full-time equivalents; In

The firm's country of origin (reference country: Austria)

Firm-specific relevance of energy related taxes

(three-level ordinary variable; level 1: 'not relevant'; level 3: 'high relevance')

Firm-specific relevance of energy related regulations and standards (three-level ordinary variable; level 1: 'not relevant'; level 3: 'high relevance')

Firm-specific relevance of industry-specific energy related voluntary agreements or standards

(three-level ordinary variable; level 1: 'not relevant'; level 3: 'high relevance')

Firm-specific relevance of energy related public subsidies

(three-level ordinary variable; level 1: 'not relevant'; level 3: 'high relevance')

Firm-specific relevance of demand for green energy products and services (three-level ordinary variable; level 1: 'not relevant'; level 3: 'high relevance')

Controls for industry affiliation on NACE two-digit codes

Importance of lack of financial resources as obstacle for green product innovation (four-level ordinary variable; level 1: 'not relevant'; level 4: 'high relevance') 
Table 2: Identification of direct (supply-side) policy effects (Tobit regressions)

\begin{tabular}{|c|c|c|c|c|c|c|c|c|c|}
\hline & (1) & (2) & (3) & $\begin{array}{c}(4) \\
\text { Green proc }\end{array}$ & $\begin{array}{c}\text { (5) } \\
\text { uct innovati }\end{array}$ & $\begin{array}{c}6) \\
n \text { intensity }\end{array}$ & (7) & (8) & (9) \\
\hline Export intensity & $\begin{array}{c}0.043 \\
(0.123)\end{array}$ & $\begin{array}{c}0.141 \\
(0.120)\end{array}$ & $\begin{array}{c}0.038 \\
(0.122)\end{array}$ & $\begin{array}{c}0.137 \\
(0.120)\end{array}$ & $\begin{array}{c}0.066 \\
(0.121)\end{array}$ & $\begin{array}{c}0.133 \\
(0.119)\end{array}$ & $\begin{array}{c}0.044 \\
(0.121)\end{array}$ & $\begin{array}{c}0.132 \\
(0.119)\end{array}$ & $\begin{array}{c}0.149 \\
(0.120)\end{array}$ \\
\hline Share of high qualified employees & $\begin{array}{c}0.447 * * * \\
(0.172)\end{array}$ & $\begin{array}{c}0.408 * * \\
(0.163)\end{array}$ & $\begin{array}{c}0.478 * * * \\
(0.170)\end{array}$ & $\begin{array}{c}0.438 * * * \\
(0.161)\end{array}$ & $\begin{array}{c}0.457 * * * \\
(0.167)\end{array}$ & $\begin{array}{c}0.448 * * * \\
(0.160)\end{array}$ & $\begin{array}{c}0.490 * * * \\
(0.170)\end{array}$ & $\begin{array}{c}0.449 * * * \\
(0.161)\end{array}$ & $\begin{array}{c}0.388 * * \\
(0.163)\end{array}$ \\
\hline Foreign owned & $\begin{array}{l}-0.340 \\
(0.480)\end{array}$ & $\begin{array}{l}-0.214 \\
(0.461)\end{array}$ & $\begin{array}{c}-0.340 \\
(0.481)\end{array}$ & $\begin{array}{l}-0.219 \\
(0.460)\end{array}$ & $\begin{array}{l}-0.196 \\
(0.476)\end{array}$ & $\begin{array}{l}-0.172 \\
(0.459)\end{array}$ & $\begin{array}{l}-0.331 \\
(0.479)\end{array}$ & $\begin{array}{l}-0.219 \\
(0.460)\end{array}$ & $\begin{array}{l}-0.138 \\
(0.459)\end{array}$ \\
\hline Firm age & $\begin{array}{c}0.011 \\
(0.209)\end{array}$ & $\begin{array}{c}0.008 \\
(0.199)\end{array}$ & $\begin{array}{c}0.009 \\
(0.208)\end{array}$ & $\begin{array}{l}-0.015 \\
(0.200)\end{array}$ & $\begin{array}{c}0.091 \\
(0.208)\end{array}$ & $\begin{array}{c}0.037 \\
(0.200)\end{array}$ & $\begin{array}{c}0.009 \\
(0.208)\end{array}$ & $\begin{array}{c}0.000 \\
(0.200)\end{array}$ & $\begin{array}{c}0.055 \\
(0.199)\end{array}$ \\
\hline Competition intensity & $\begin{array}{c}1.074 * * * \\
(0.366)\end{array}$ & $\begin{array}{c}0.782 * * \\
(0.349)\end{array}$ & $\begin{array}{c}1.052 * * * \\
(0.366)\end{array}$ & $\begin{array}{c}0.759 * * \\
(0.349)\end{array}$ & $\begin{array}{c}0.996 * * * \\
(0.358)\end{array}$ & $\begin{array}{c}0.769 * * \\
(0.348)\end{array}$ & $\begin{array}{c}1.038 * * * \\
(0.363)\end{array}$ & $\begin{array}{c}0.764 * * \\
(0.349)\end{array}$ & $\begin{array}{c}0.786 * * \\
(0.345)\end{array}$ \\
\hline$R \& D$ propensity & $\begin{array}{c}1.811^{* * *} \\
(0.396)\end{array}$ & $\begin{array}{c}1.755^{* * *} \\
(0.383)\end{array}$ & $\begin{array}{c}1.818 * * * \\
(0.394)\end{array}$ & $\begin{array}{c}1.772 * * * \\
(0.381)\end{array}$ & $\begin{array}{c}1.788^{* * *} \\
(0.393)\end{array}$ & $\begin{array}{c}1.765 * * * \\
(0.382)\end{array}$ & $\begin{array}{c}1.784 * * * \\
(0.396)\end{array}$ & $\begin{array}{c}1.772^{* * *} \\
(0.382)\end{array}$ & $\begin{array}{c}1.755^{* * *} \\
(0.384)\end{array}$ \\
\hline Green process innovation intensity & $\begin{array}{c}0.247 * * * \\
(0.050)\end{array}$ & $\begin{array}{c}0.185^{* * *} \\
(0.050)\end{array}$ & $\begin{array}{c}0.230 * * * \\
(0.049)\end{array}$ & $\begin{array}{c}0.176^{* * *} \\
(0.049)\end{array}$ & $\begin{array}{c}0.172^{* * *} \\
(0.049)\end{array}$ & $\begin{array}{c}0.152^{* * *} \\
(0.049)\end{array}$ & $\begin{array}{c}0.217^{* * *} \\
(0.049)\end{array}$ & $\begin{array}{c}0.170 * * * \\
(0.049)\end{array}$ & $\begin{array}{c}0.167^{* * *} \\
(0.049)\end{array}$ \\
\hline Products not suited & $\begin{array}{c}-0.580 * * * \\
(0.146)\end{array}$ & $\begin{array}{c}-0.497^{* * *} \\
(0.149)\end{array}$ & $\begin{array}{c}-0.590 * * * \\
(0.146)\end{array}$ & $\begin{array}{c}-0.508^{* * *} \\
(0.149)\end{array}$ & $\begin{array}{c}-0.587 * * * \\
(0.147)\end{array}$ & $\begin{array}{c}-0.519 * * * \\
(0.149)\end{array}$ & $\begin{array}{c}-0.594^{* * *} \\
(0.147)\end{array}$ & $\begin{array}{c}-0.512 * * * \\
(0.150)\end{array}$ & $\begin{array}{c}-0.503 * * * \\
(0.148)\end{array}$ \\
\hline Number of employees & $\begin{array}{c}0.229 * * \\
(0.115)\end{array}$ & $\begin{array}{c}0.092 \\
(0.112)\end{array}$ & $\begin{array}{l}0.196^{*} \\
(0.115)\end{array}$ & $\begin{array}{c}0.087 \\
(0.113)\end{array}$ & $\begin{array}{c}0.146 \\
(0.113)\end{array}$ & $\begin{array}{c}0.058 \\
(0.112)\end{array}$ & $\begin{array}{c}0.180 \\
(0.115)\end{array}$ & $\begin{array}{c}0.066 \\
(0.113)\end{array}$ & $\begin{array}{c}0.099 \\
(0.111)\end{array}$ \\
\hline Swiss firm & $\begin{array}{l}-0.682 \\
(0.559)\end{array}$ & $\begin{array}{l}-0.730 \\
(0.532)\end{array}$ & $\begin{array}{l}-0.775 \\
(0.556)\end{array}$ & $\begin{array}{l}-0.685 \\
(0.530)\end{array}$ & $\begin{array}{l}-0.654 \\
(0.542)\end{array}$ & $\begin{array}{l}-0.762 \\
(0.525)\end{array}$ & $\begin{array}{l}-0.792 \\
(0.548)\end{array}$ & $\begin{array}{l}-0.791 \\
(0.526)\end{array}$ & $\begin{array}{l}-0.585 \\
(0.533)\end{array}$ \\
\hline German firm & $\begin{array}{c}-1.638 * * * \\
(0.561)\end{array}$ & $\begin{array}{c}-1.778^{* * *} \\
(0.528)\end{array}$ & $\begin{array}{c}-1.831 * * * \\
(0.551)\end{array}$ & $\begin{array}{c}-1.933 * * * \\
(0.519)\end{array}$ & $\begin{array}{c}-1.814^{* * *} \\
(0.536)\end{array}$ & $\begin{array}{c}-1.987^{* * *} \\
(0.515)\end{array}$ & $\begin{array}{c}-1.855^{* * *} \\
(0.540)\end{array}$ & $\begin{array}{c}-1.999 * * * \\
(0.518)\end{array}$ & $\begin{array}{c}-1.690 * * * \\
(0.524)\end{array}$ \\
\hline Taxes & $\begin{array}{c}-0.453^{*} \\
(0.237)\end{array}$ & $\begin{array}{c}-0.640 * * * \\
(0.232)\end{array}$ & & & & & & & $\begin{array}{c}-0.663^{* * *} \\
(0.250)\end{array}$ \\
\hline Regulations & & & $\begin{array}{c}0.110 \\
(0.246)\end{array}$ & $\begin{array}{c}-0.420^{*} \\
(0.241)\end{array}$ & & & & & $\begin{array}{c}-0.337 \\
(0.280)\end{array}$ \\
\hline Public subsidies & & & & & $\begin{array}{c}1.174 * * * \\
(0.206)\end{array}$ & $\begin{array}{l}0.423^{*} \\
(0.220)\end{array}$ & & & $\begin{array}{c}0.689 * * * \\
(0.245)\end{array}$ \\
\hline Voluntary agreements & & & & & & & $\begin{array}{c}0.487^{* *} \\
(0.243)\end{array}$ & $\begin{array}{l}-0.087 \\
(0.234)\end{array}$ & $\begin{array}{c}0.027 \\
(0.263)\end{array}$ \\
\hline Demand & & $\begin{array}{c}1.917 * * * \\
(0.192)\end{array}$ & & $\begin{array}{c}1.952 * * * \\
(0.196)\end{array}$ & & $\begin{array}{c}1.672 * * * \\
(0.214)\end{array}$ & & $\begin{array}{c}1.879 * * * \\
(0.196)\end{array}$ & $\begin{array}{c}1.692 * * * \\
(0.212)\end{array}$ \\
\hline Industry controls & yes & yes & yes & yes & yes & yes & yes & yes & yes \\
\hline $\mathrm{N}$ & 1987 & 1987 & 1987 & 1987 & 1987 & 1987 & 1987 & 1987 & 1987 \\
\hline Walc & $123.74 * * *$ & $271.22 * * *$ & $123.91 * * *$ & $270.58 * * *$ & $173.49 * * *$ & $266.87 * * *$ & $132.71 * * *$ & $263.01 * * *$ & $284.67^{* * *}$ \\
\hline Log Likelihood & -922.51 & -880.23 & -924.26 & -882.67 & -909.69 & -882.57 & -922.38 & -884.17 & -876.12 \\
\hline
\end{tabular}

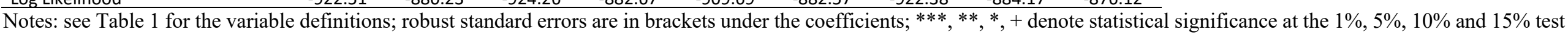
level, respectively; all models include a constant term. 
Table 3: Compare policy effects on process and product innovation (Tobit regressions)

\begin{tabular}{|c|c|c|}
\hline & (1) & (2) \\
\hline & Green product innovation intensity & Green process innovation intensity \\
\hline \multirow[t]{2}{*}{ Export intensity } & 0.149 & 0.166 \\
\hline & $(0.120)$ & $(0.118)$ \\
\hline \multirow[t]{2}{*}{ Share of high qualified employees } & $0.388 * *$ & 0.164 \\
\hline & $(0.163)$ & $(0.160)$ \\
\hline \multirow[t]{2}{*}{ Foreign owned } & -0.138 & 0.077 \\
\hline & $(0.459)$ & $(0.468)$ \\
\hline \multirow[t]{2}{*}{ Firm age } & 0.055 & $0.594 * * *$ \\
\hline & (0.199) & $(0.209)$ \\
\hline \multirow[t]{2}{*}{ Competition intensity } & $0.786 * *$ & 0.061 \\
\hline & $(0.345)$ & $(0.341)$ \\
\hline \multirow[t]{2}{*}{ R\&D propensity } & $1.755^{* * *}$ & $1.739 * * *$ \\
\hline & $(0.384)$ & $(0.372)$ \\
\hline \multirow[t]{2}{*}{ Green process innovation intensity } & $0.167 * * *$ & \\
\hline & $(0.049)$ & \\
\hline \multirow{2}{*}{ Products not suited } & $-0.503 * * *$ & 0.124 \\
\hline & $(0.148)$ & $(0.137)$ \\
\hline \multirow[t]{2}{*}{ Number of employees } & 0.099 & $0.818 * * *$ \\
\hline & (0.111) & $(0.116)$ \\
\hline \multirow[t]{2}{*}{ Swiss firm } & -0.585 & $-1.376 * *$ \\
\hline & $(0.533)$ & $(0.615)$ \\
\hline \multirow[t]{2}{*}{ German firm } & $-1.690 * * *$ & 0.303 \\
\hline & $(0.524)$ & (0.598) \\
\hline \multirow[t]{2}{*}{ Taxes } & $-0.663 * * *$ & $0.649 * * *$ \\
\hline & $(0.250)$ & $(0.247)$ \\
\hline \multirow[t]{2}{*}{ Regulations } & -0.337 & 0.122 \\
\hline & $(0.280)$ & $(0.268)$ \\
\hline \multirow[t]{2}{*}{ Public subsidies } & $0.689 * * *$ & $1.264 * * *$ \\
\hline & $(0.245)$ & $(0.248)$ \\
\hline \multirow[t]{2}{*}{ Voluntary agreements } & 0.027 & $0.455^{*}$ \\
\hline & $(0.263)$ & $(0.263)$ \\
\hline \multirow[t]{2}{*}{ Demand } & $1.692 * * *$ & $0.518^{* *}$ \\
\hline & $(0.212)$ & $(0.258)$ \\
\hline Industry controls & yes & yes \\
\hline $\mathrm{N}$ & 1987 & 1987 \\
\hline Wald chi2 & $284.67 * * *$ & $1428.39 * * *$ \\
\hline Log Likelihood & -876.12 & -3282.57 \\
\hline
\end{tabular}

Notes: see Table 1 for the variable definitions; robust standard errors are in brackets under the coefficients; ***, **, $*,+$ denote statistical significance at the $1 \%, 5 \%, 10 \%$ and $15 \%$ test level, respectively; all models include a constant term. 
Table 4: Test the moderating effect of green process innovation (Tobit regressions)

\begin{tabular}{|c|c|c|c|c|c|c|}
\hline & (1) & (2) & $\begin{array}{c}\text { (3) } \\
n \text { product in }\end{array}$ & $\begin{array}{c}\text { (4) } \\
\text { vation inte }\end{array}$ & nsity $^{(5)}$ & (6) \\
\hline Export intensity & $\begin{array}{c}0.150 \\
(0.111)\end{array}$ & $\begin{array}{c}0.048 \\
(0.116)\end{array}$ & $\begin{array}{c}0.149 \\
(0.112)\end{array}$ & $\begin{array}{c}0.150 \\
(0.112)\end{array}$ & $\begin{array}{c}0.149 \\
(0.112)\end{array}$ & $\begin{array}{c}0.149 \\
(0.119)\end{array}$ \\
\hline Share of high qualified employees & $\begin{array}{c}0.399 * * \\
(0.163)\end{array}$ & $\begin{array}{c}0.459 * * * \\
(0.172)\end{array}$ & $\begin{array}{c}0.390 * * \\
(0.164)\end{array}$ & $\begin{array}{c}0.388^{* * *} \\
(0.163)\end{array}$ & $\begin{array}{c}0.388^{* * *} \\
(0.164)\end{array}$ & $\begin{array}{c}0.395^{* *} \\
(0.164)\end{array}$ \\
\hline Foreign owned & $\begin{array}{l}-0.138 \\
(0.453)\end{array}$ & $\begin{array}{l}-0.336 \\
(0.481)\end{array}$ & $\begin{array}{l}-0.145 \\
(0.454)\end{array}$ & $\begin{array}{l}-0.138 \\
(0.453)\end{array}$ & $\begin{array}{c}-0.138 \\
(0.453)\end{array}$ & $\begin{array}{l}-0.128 \\
(0.459)\end{array}$ \\
\hline Firm age & $\begin{array}{c}0.052 \\
(0.207)\end{array}$ & $\begin{array}{c}0.008 \\
(0.214)\end{array}$ & $\begin{array}{c}0.054 \\
(0.208)\end{array}$ & $\begin{array}{c}0.055 \\
(0.208)\end{array}$ & $\begin{array}{c}0.055 \\
(0.208)\end{array}$ & $\begin{array}{c}0.053 \\
(0.198)\end{array}$ \\
\hline Competition intensity & $\begin{array}{c}0.802 * * \\
(0.340)\end{array}$ & $\begin{array}{c}1.098^{* * *} \\
(0.361)\end{array}$ & $\begin{array}{c}0.787^{* *} \\
(0.340)\end{array}$ & $\begin{array}{c}0.784 * * \\
(0.340)\end{array}$ & $\begin{array}{l}0.786^{* * *} \\
(0.340)\end{array}$ & $\begin{array}{c}0.806^{* *} \\
(0.342)\end{array}$ \\
\hline R\&D propensity & $\begin{array}{c}1.756^{* * *} \\
(0.379)\end{array}$ & $\begin{array}{c}1.815^{* * *} \\
(0.394)\end{array}$ & $\begin{array}{c}1.755^{* * *} \\
(0.380)\end{array}$ & $\begin{array}{c}1.757^{* * * *} \\
(0.380)\end{array}$ & $\begin{array}{c}1.755^{* * *} \\
(0.380)\end{array}$ & $\begin{array}{c}1.756 * * * \\
(0.382)\end{array}$ \\
\hline Green process innovation intensity & $\begin{array}{c}0.353^{* * *} \\
(0.119)\end{array}$ & $\begin{array}{l}0.000 \\
(.)\end{array}$ & $\begin{array}{l}0.198^{*} \\
(0.113)\end{array}$ & $\begin{array}{l}0.183+ \\
(0.113)\end{array}$ & $\begin{array}{l}0.164+ \\
(0.111)\end{array}$ & $\begin{array}{c}0.289^{* *} \\
(0.143)\end{array}$ \\
\hline Products not suited & $\begin{array}{c}-0.528^{* * * *} \\
(0.157)\end{array}$ & $\begin{array}{c}-0.609 * * * \\
(0.162)\end{array}$ & $\begin{array}{c}-0.505^{* * * *} \\
(0.156)\end{array}$ & $\begin{array}{c}-0.503^{* * *} \\
(0.156)\end{array}$ & $\begin{array}{c}-0.503^{* * *} \\
(0.156)\end{array}$ & $\begin{array}{c}-0.530^{* * *} \\
(0.148)\end{array}$ \\
\hline Number of employees & $\begin{array}{c}0.112 \\
(0.110)\end{array}$ & $\begin{array}{c}0.241^{* *} \\
(0.115)\end{array}$ & $\begin{array}{c}0.101 \\
(0.110)\end{array}$ & $\begin{array}{c}0.099 \\
(0.110)\end{array}$ & $\begin{array}{c}0.099 \\
(0.110)\end{array}$ & $\begin{array}{c}0.110 \\
(0.111)\end{array}$ \\
\hline Swiss firm & $\begin{array}{c}-0.589 \\
(0.537)\end{array}$ & $\begin{array}{l}-0.683 \\
(0.565)\end{array}$ & $\begin{array}{l}-0.581 \\
(0.539)\end{array}$ & $\begin{array}{l}-0.579 \\
(0.540)\end{array}$ & $\begin{array}{c}-0.586 \\
(0.539)\end{array}$ & $\begin{array}{l}-0.611 \\
(0.540)\end{array}$ \\
\hline German firm & $\begin{array}{c}-1.695 * * * \\
(0.551)\end{array}$ & $\begin{array}{c}-1.631 * * * \\
(0.581)\end{array}$ & $\begin{array}{c}-1.691 * * * \\
(0.552)\end{array}$ & $\begin{array}{c}-1.683^{* * * *} \\
(0.553)\end{array}$ & $\begin{array}{c}-1.690 * * * \\
(0.552)\end{array}$ & $\begin{array}{c}-1.705^{* * * *} \\
(0.528)\end{array}$ \\
\hline Taxes & $\begin{array}{l}-0.228 \\
(0.354)\end{array}$ & $\begin{array}{c}0.085 \\
(0.345)\end{array}$ & $\begin{array}{c}-0.662^{* *} \\
(0.261)\end{array}$ & $\begin{array}{c}-0.663^{* *} \\
(0.261)\end{array}$ & $\begin{array}{c}-0.663^{* *} \\
(0.261)\end{array}$ & $\begin{array}{c}-0.110 \\
(0.370)\end{array}$ \\
\hline Regulations & $\begin{array}{l}-0.325 \\
(0.290)\end{array}$ & & $\begin{array}{l}-0.251 \\
(0.399)\end{array}$ & $\begin{array}{l}-0.340 \\
(0.292)\end{array}$ & $\begin{array}{c}-0.337 \\
(0.291)\end{array}$ & $\begin{array}{l}-0.471 \\
(0.477)\end{array}$ \\
\hline Public subsidies & $\begin{array}{c}0.669^{* * *} \\
(0.253)\end{array}$ & & $\begin{array}{c}0.686^{* * *} \\
(0.254)\end{array}$ & $\begin{array}{c}0.686^{* * * *} \\
(0.254)\end{array}$ & $\begin{array}{l}0.681^{*} \\
(0.366)\end{array}$ & $\begin{array}{c}0.550 \\
(0.417)\end{array}$ \\
\hline Voluntary agreements & $\begin{array}{c}0.034 \\
(0.274)\end{array}$ & & $\begin{array}{c}0.023 \\
(0.275)\end{array}$ & $\begin{array}{c}0.078 \\
(0.415)\end{array}$ & $\begin{array}{c}0.027 \\
(0.275)\end{array}$ & $\begin{array}{c}0.011 \\
(0.467)\end{array}$ \\
\hline Demand & $\begin{array}{c}1.680^{* * *} \\
(0.242)\end{array}$ & & $\begin{array}{c}1.690^{* * *} \\
(0.242)\end{array}$ & $\begin{array}{c}1.691^{* * *} \\
(0.242)\end{array}$ & $\begin{array}{c}1.692^{* * *} \\
(0.244)\end{array}$ & $\begin{array}{c}1.692^{* * *} \\
(0.212)\end{array}$ \\
\hline Green process innovation intensity \# Taxes & $\begin{array}{l}-0.113^{*} \\
(0.065)\end{array}$ & $\begin{array}{c}-0.140 * * \\
(0.068)\end{array}$ & & & & $\begin{array}{c}-0.144^{* *} \\
(0.073)\end{array}$ \\
\hline Green process innovation intensity \# Regulations & & & $\begin{array}{l}-0.021 \\
(0.067)\end{array}$ & & & $\begin{array}{c}0.038 \\
(0.091)\end{array}$ \\
\hline Green process innovation intensity \# Voluntary agree & nents & & & $\begin{array}{l}-0.012 \\
(0.071)\end{array}$ & & $\begin{array}{c}0.008 \\
(0.087)\end{array}$ \\
\hline Green process innovation intensity \# Public subsidies & & & & & $\begin{array}{c}0.002 \\
(0.063)\end{array}$ & $\begin{array}{c}0.029 \\
(0.074)\end{array}$ \\
\hline Industry controls & yes & yes & yes & yes & yes & yes \\
\hline N Wald chi2 & $\begin{array}{c}1987 \\
297.48^{* * *} \\
-874.60\end{array}$ & $\begin{array}{c}1987 \\
205.94^{* * *} \\
-920.37\end{array}$ & $\begin{array}{c}1987 \\
294.53^{* * *} \\
-876.08\end{array}$ & $\begin{array}{c}1987 \\
294.46^{* * *} \\
-876.11\end{array}$ & $\begin{array}{c}1987 \\
294.44^{* * *} \\
-876.12\end{array}$ & $\begin{array}{c}1987 \\
309.37^{* * *} \\
-874.28\end{array}$ \\
\hline
\end{tabular}

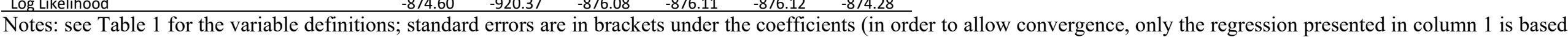
on robust standard errors); $* * * * *, *,+$ denote statistical significance at the $1 \%, 5 \%, 10 \%$ and $15 \%$ test level, respectively; all models include a constant term. 
Table 5: Policy effect by degree of innovativeness (multinomial logit regressions; reference category: no green product innovation)

\begin{tabular}{|c|c|c|c|c|c|c|c|c|c|c|c|c|}
\hline & $\begin{array}{c}\text { (1) } \\
\text { New to the } \\
\text { firm }\end{array}$ & $\begin{array}{c}\text { (2) } \\
\text { New to the } \\
\text { market }\end{array}$ & $\begin{array}{c}\text { (3) } \\
\text { New to the } \\
\text { firm }\end{array}$ & $\begin{array}{c}\text { (4) } \\
\text { New to the } \\
\text { market }\end{array}$ & $\begin{array}{l}\text { (5) } \\
\text { New to the } \\
\text { firm }\end{array}$ & $\begin{array}{c}\text { (6) } \\
\text { New to the } \\
\text { market }\end{array}$ & $\begin{array}{l}\text { (7) } \\
\text { New to the } \\
\text { firm }\end{array}$ & $\begin{array}{c}\text { (8) } \\
\text { New to the } \\
\text { market }\end{array}$ & $\begin{array}{l}\text { (9) } \\
\text { New to the } \\
\text { firm }\end{array}$ & $\begin{array}{c}(10) \\
\text { New to the } \\
\text { market }\end{array}$ & $\begin{array}{l}\text { (11) } \\
\text { New to the } \\
\text { firm }\end{array}$ & $\begin{array}{c}(12) \\
\text { New to the } \\
\text { market }\end{array}$ \\
\hline Export intensity & $\begin{array}{c}-0.034 \\
(0.067)\end{array}$ & $\begin{array}{c}0.008 \\
(0.085)\end{array}$ & $\begin{array}{c}-0.034 \\
(0.067)\end{array}$ & $\begin{array}{c}0.005 \\
(0.085)\end{array}$ & $\begin{array}{l}-0.084 \\
(0.065)\end{array}$ & $\begin{array}{l}-0.075 \\
(0.081)\end{array}$ & $\begin{array}{c}-0.038 \\
(0.067)\end{array}$ & $\begin{array}{c}0.008 \\
(0.085)\end{array}$ & $\begin{array}{c}-0.039 \\
(0.066)\end{array}$ & $\begin{array}{c}0.006 \\
(0.086)\end{array}$ & $\begin{array}{l}-0.025 \\
(0.067)\end{array}$ & $\begin{array}{c}0.010 \\
(0.086)\end{array}$ \\
\hline Share of high qualified employees & $\begin{array}{l}0.146+ \\
(0.094)\end{array}$ & $\begin{array}{c}0.269 * * \\
(0.131)\end{array}$ & $\begin{array}{l}0.157^{*} \\
(0.093)\end{array}$ & $\begin{array}{c}0.277^{* *} \\
(0.131)\end{array}$ & $\begin{array}{l}0.169 * \\
(0.092)\end{array}$ & $\begin{array}{l}0.267 * * \\
(0.128)\end{array}$ & $\begin{array}{l}0.176^{*} \\
(0.093)\end{array}$ & $\begin{array}{c}0.272^{* *} \\
(0.131)\end{array}$ & $\begin{array}{l}0.172^{*} \\
(0.093)\end{array}$ & $\begin{array}{c}0.273 * * \\
(0.130)\end{array}$ & $\begin{array}{l}0.140+ \\
(0.094)\end{array}$ & $\begin{array}{l}0.250^{*} \\
(0.131)\end{array}$ \\
\hline Foreign owned & $\begin{array}{c}-0.032 \\
(0.275)\end{array}$ & $\begin{array}{l}-0.160 \\
(0.323)\end{array}$ & $\begin{array}{l}-0.024 \\
(0.276)\end{array}$ & $\begin{array}{l}-0.169 \\
(0.324)\end{array}$ & $\begin{array}{l}-0.053 \\
(0.271)\end{array}$ & $\begin{array}{l}-0.191 \\
(0.313)\end{array}$ & $\begin{array}{l}-0.021 \\
(0.275)\end{array}$ & $\begin{array}{l}-0.127 \\
(0.324)\end{array}$ & $\begin{array}{l}-0.034 \\
(0.275)\end{array}$ & $\begin{array}{l}-0.163 \\
(0.323)\end{array}$ & $\begin{array}{c}0.002 \\
(0.277)\end{array}$ & $\begin{array}{l}-0.129 \\
(0.326)\end{array}$ \\
\hline Firm age & $\begin{array}{c}0.080 \\
(0.120)\end{array}$ & $\begin{array}{l}-0.015 \\
(0.146)\end{array}$ & $\begin{array}{c}0.079 \\
(0.120)\end{array}$ & $\begin{array}{l}-0.011 \\
(0.146)\end{array}$ & $\begin{array}{l}0.066 \\
(0.117)\end{array}$ & $\begin{array}{l}0.012 \\
(0.140)\end{array}$ & $\begin{array}{c}0.082 \\
(0.119)\end{array}$ & $\begin{array}{c}0.010 \\
(0.147)\end{array}$ & $\begin{array}{c}0.080 \\
(0.119)\end{array}$ & $\begin{array}{l}-0.013 \\
(0.146)\end{array}$ & $\begin{array}{c}0.087 \\
(0.121)\end{array}$ & $\begin{array}{c}0.021 \\
(0.149)\end{array}$ \\
\hline Competition intensity & $\begin{array}{l}0.290+ \\
(0.197)\end{array}$ & $\begin{array}{c}0.268 \\
(0.236)\end{array}$ & $\begin{array}{l}0.292+ \\
(0.197)\end{array}$ & $\begin{array}{c}0.272 \\
(0.236)\end{array}$ & $\begin{array}{l}0.342^{*} \\
(0.194)\end{array}$ & $\begin{array}{l}0.401^{*} \\
(0.228)\end{array}$ & $\begin{array}{l}0.292+ \\
(0.196)\end{array}$ & $\begin{array}{c}0.289 \\
(0.237)\end{array}$ & $\begin{array}{l}0.289+ \\
(0.196)\end{array}$ & $\begin{array}{c}0.266 \\
(0.236)\end{array}$ & $\begin{array}{l}0.298+ \\
(0.198)\end{array}$ & $\begin{array}{c}0.294 \\
(0.238)\end{array}$ \\
\hline R\&D propensity & $\begin{array}{c}0.595^{* * *} * \\
(0.216)\end{array}$ & $\begin{array}{c}1.508 * * * \\
(0.317)\end{array}$ & $\begin{array}{c}0.605 * * * \\
(0.216)\end{array}$ & $\begin{array}{c}1.522 * * * \\
(0.317)\end{array}$ & $\begin{array}{l}0.588^{* * *} \\
(0.211)\end{array}$ & $\begin{array}{l}1.499 * * * \\
(0.308)\end{array}$ & $\begin{array}{c}0.590 * * * \\
(0.215)\end{array}$ & $\begin{array}{c}1.502 * * * \\
(0.317)\end{array}$ & $\begin{array}{c}0.598 * * * \\
(0.215)\end{array}$ & $\begin{array}{c}1.513 * * * \\
(0.316)\end{array}$ & $\begin{array}{c}0.600 * * * \\
(0.218)\end{array}$ & $\begin{array}{c}1.513 * * * \\
(0.318)\end{array}$ \\
\hline Green process innovation intensity & $\begin{array}{c}0.042 \\
(0.029)\end{array}$ & $\begin{array}{c}0.110 * * * \\
(0.036)\end{array}$ & $\begin{array}{c}0.041 \\
(0.029)\end{array}$ & $\begin{array}{c}0.106 * * * \\
(0.036)\end{array}$ & $\begin{array}{l}0.060 * * \\
(0.028)\end{array}$ & $\begin{array}{l}0.120 * * * \\
(0.034)\end{array}$ & $\begin{array}{c}0.029 \\
(0.029)\end{array}$ & $\begin{array}{c}0.097^{* * *} * \\
(0.036)\end{array}$ & $\begin{array}{c}0.034 \\
(0.029)\end{array}$ & $\begin{array}{c}0.108 * * * \\
(0.036)\end{array}$ & $\begin{array}{c}0.037 \\
(0.030)\end{array}$ & $\begin{array}{c}0.103 * * * \\
(0.036)\end{array}$ \\
\hline Products not suited & $\begin{array}{l}-0.044 \\
(0.081)\end{array}$ & $\begin{array}{c}-0.351 * * * \\
(0.122)\end{array}$ & $\begin{array}{l}-0.041 \\
(0.081)\end{array}$ & $\begin{array}{c}-0.353 * * * \\
(0.122)\end{array}$ & $\begin{array}{l}-0.066 \\
(0.078)\end{array}$ & $\begin{array}{l}-0.350^{* * *} \\
(0.114)\end{array}$ & $\begin{array}{l}-0.048 \\
(0.081)\end{array}$ & $\begin{array}{c}-0.350 * * * \\
(0.122)\end{array}$ & $\begin{array}{l}-0.046 \\
(0.081)\end{array}$ & $\begin{array}{c}-0.349 * * * \\
(0.122)\end{array}$ & $\begin{array}{l}-0.042 \\
(0.081)\end{array}$ & $\begin{array}{c}-0.341 * * * \\
(0.122)\end{array}$ \\
\hline Number of employees & $\begin{array}{l}0.123^{*} \\
(0.065)\end{array}$ & $\begin{array}{c}0.197 * * \\
(0.078)\end{array}$ & $\begin{array}{l}0.129 * \\
(0.066)\end{array}$ & $\begin{array}{c}0.188 * * \\
(0.078)\end{array}$ & $\begin{array}{l}0.161 * * \\
(0.064)\end{array}$ & $\begin{array}{l}0.228 * * * \\
(0.075)\end{array}$ & $\begin{array}{l}0.106+ \\
(0.065)\end{array}$ & $\begin{array}{c}0.188 * * \\
(0.078)\end{array}$ & $\begin{array}{l}0.111^{*} \\
(0.065)\end{array}$ & $\begin{array}{c}0.196 * * \\
(0.078)\end{array}$ & $\begin{array}{l}0.129 * \\
(0.066)\end{array}$ & $\begin{array}{c}0.193 * * \\
(0.078)\end{array}$ \\
\hline Swiss firm & $\begin{array}{c}-0.684^{* *} \\
(0.317)\end{array}$ & $\begin{array}{l}-0.662^{*} \\
(0.354)\end{array}$ & $\begin{array}{c}-0.631 * * \\
(0.318)\end{array}$ & $\begin{array}{l}-0.674^{*} \\
(0.354)\end{array}$ & $\begin{array}{l}-0.625^{* *} \\
(0.313)\end{array}$ & $\begin{array}{l}-0.808^{* *} \\
(0.341)\end{array}$ & $\begin{array}{c}-0.694^{* *} \\
(0.317)\end{array}$ & $\begin{array}{l}-0.636^{*} \\
(0.354)\end{array}$ & $\begin{array}{c}-0.696 * * \\
(0.316)\end{array}$ & $\begin{array}{l}-0.661^{*} \\
(0.354)\end{array}$ & $\begin{array}{l}-0.573^{*} \\
(0.321)\end{array}$ & $\begin{array}{l}-0.608^{*} \\
(0.358)\end{array}$ \\
\hline German firm & $\begin{array}{l}-0.293 \\
(0.311)\end{array}$ & $\begin{array}{c}-0.689 * * \\
(0.349)\end{array}$ & $\begin{array}{l}-0.362 \\
(0.308)\end{array}$ & $\begin{array}{c}-0.737^{* *} \\
(0.345)\end{array}$ & $\begin{array}{l}-0.331 \\
(0.303)\end{array}$ & $\begin{array}{l}-0.705^{* *} \\
(0.333)\end{array}$ & $\begin{array}{l}-0.410 \\
(0.308)\end{array}$ & $\begin{array}{c}-0.717^{* *} \\
(0.345)\end{array}$ & $\begin{array}{l}-0.406 \\
(0.308)\end{array}$ & $\begin{array}{c}-0.718^{* *} \\
(0.345)\end{array}$ & $\begin{array}{l}-0.252 \\
(0.313)\end{array}$ & $\begin{array}{l}-0.652^{*} \\
(0.352)\end{array}$ \\
\hline Taxes & $\begin{array}{c}-0.347 * * * \\
(0.134)\end{array}$ & $\begin{array}{l}-0.115 \\
(0.160)\end{array}$ & & & & & & & & & $\begin{array}{l}-0.243+ \\
(0.148)\end{array}$ & $\begin{array}{l}-0.178 \\
(0.180)\end{array}$ \\
\hline Regulations & & & $\begin{array}{c}-0.488^{* * *} \\
(0.151)\end{array}$ & $\begin{array}{c}0.015 \\
(0.162)\end{array}$ & $\begin{array}{l}-0.238^{*} \\
(0.143)\end{array}$ & $\begin{array}{l}0.342 * * \\
(0.151)\end{array}$ & & & & & $\begin{array}{c}-0.524 * * * \\
(0.181)\end{array}$ & $\begin{array}{c}0.076 \\
(0.196)\end{array}$ \\
\hline Public subsidies & & & & & & & $\begin{array}{c}0.088 \\
(0.135)\end{array}$ & $\begin{array}{l}0.263^{*} \\
(0.154)\end{array}$ & & & $\begin{array}{l}0.272^{*} \\
(0.149)\end{array}$ & $\begin{array}{c}0.357^{* *} \\
(0.169)\end{array}$ \\
\hline Voluntary agreements & & & & & & & & & $\begin{array}{l}-0.106 \\
(0.145)\end{array}$ & $\begin{array}{l}-0.126 \\
(0.166)\end{array}$ & $\begin{array}{c}0.117 \\
(0.170)\end{array}$ & $\begin{array}{l}-0.228 \\
(0.189)\end{array}$ \\
\hline Demand & $\begin{array}{c}0.843 * * * \\
(0.120)\end{array}$ & $\begin{array}{c}1.163 * * * \\
(0.143)\end{array}$ & $\begin{array}{c}0.914 * * * \\
(0.125)\end{array}$ & $\begin{array}{c}1.146 * * * \\
(0.147)\end{array}$ & & & $\begin{array}{c}0.760 * * * \\
(0.133)\end{array}$ & $\begin{array}{c}1.035 * * * \\
(0.155)\end{array}$ & $\begin{array}{c}0.828 * * * \\
(0.124)\end{array}$ & $\begin{array}{c}1.179 * * * \\
(0.148)\end{array}$ & $\begin{array}{c}0.805 * * * \\
(0.135)\end{array}$ & $\begin{array}{c}1.061 * * * \\
(0.158)\end{array}$ \\
\hline Industry controls & yes & yes & yes & yes & yes & yes & yes & yes & yes & yes & yes & yes \\
\hline $\mathrm{N}$ & \multicolumn{2}{|c|}{1981} & \multicolumn{2}{|c|}{1981} & \multicolumn{2}{|c|}{1981} & \multicolumn{2}{|c|}{1981} & \multicolumn{2}{|c|}{1981} & \multicolumn{2}{|c|}{1981} \\
\hline $\begin{array}{l}\text { pseudo R2 } \\
\text { Wald chi2 }\end{array}$ & \multicolumn{2}{|c|}{0.18} & \multicolumn{2}{|c|}{0.19} & \multicolumn{2}{|c|}{0.14} & \multicolumn{2}{|c|}{0.18} & \multicolumn{2}{|c|}{0.18} & \multicolumn{2}{|c|}{0.19} \\
\hline Log Likelihood & \multicolumn{2}{|c|}{$371.71 * * *$} & \multicolumn{2}{|c|}{$\begin{array}{c}376.50^{* * *} \\
-821.08\end{array}$} & \multicolumn{2}{|c|}{$\begin{array}{c}280.35 * * * \\
-869.15\end{array}$} & \multicolumn{2}{|c|}{$\begin{array}{c}367.69 * * * \\
-825.48\end{array}$} & \multicolumn{2}{|c|}{-826.51} & \multicolumn{2}{|c|}{-815.58} \\
\hline
\end{tabular}

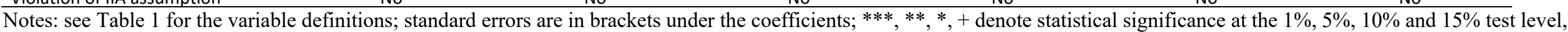
respectively; all models include a constant term. In order to allow convergence, tests of independence of irrelevance alternatives (IIA) include sector controls only. 
Table 6: Test the moderating effect of financial awareness (Tobit regressions)

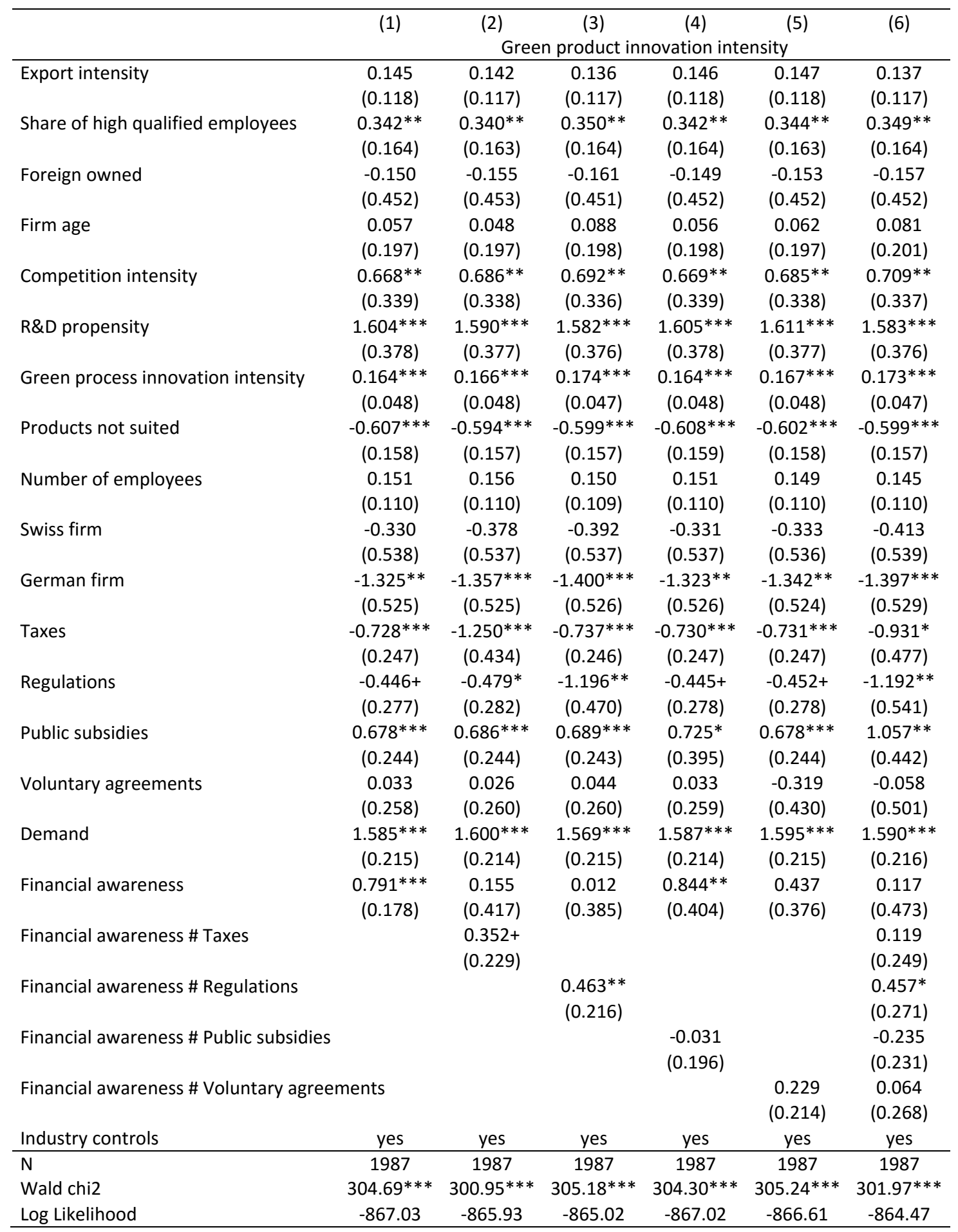

Notes: see Table 1 for the variable definitions; robust standard errors are in brackets under the coefficients; ***, **, $*,+$ denote statistical significance at the $1 \%, 5 \%, 10 \%$ and $15 \%$ test level, respectively; all models include a constant term. 
Table A.1: Descriptive statistics; based on basic model (column (9) of Table 2; N=1987)

\begin{tabular}{lcccc} 
& Mean & Std. Dev. & Min & Max \\
\hline Green product innovation propensity & 0,14 & 0,34 & 0 & 1 \\
Green product innovation intensity & 1,81 & 9,16 & 0 & 100 \\
Taxes & 1,69 & 0,73 & 1 & 3 \\
Regulations & 1,47 & 0,68 & 1 & 3 \\
Public subsidies & 1,38 & 0,62 & 1 & 3 \\
Voluntary agreements & 1,44 & 0,68 & 1 & 3 \\
Demand & 1,35 & 0,62 & 1 & 3 \\
Export intensity & 27,24 & 33,62 & 0 & 100 \\
Share of high qualified employees & 21,60 & 26,42 & 0 & 100 \\
Foreign owned & 0,12 & 0,33 & 0 & 1 \\
Firm age & 46,11 & 38,34 & 1 & 260 \\
Competition intensity & 0,69 & 0,46 & 0 & 1 \\
R\&D propensity & 0,50 & 0,50 & 0 & 1 \\
Green process innovation intensity & 587,42 & 1922,07 & 0 & 41666,67 \\
Products not suited & 1,77 & 1,12 & 1 & 4 \\
Number of employees & 276,45 & 3105,67 & 1 & 112305 \\
Swiss firm & 0,44 & 0,50 & 0 & 1 \\
German firm & 0,49 & 0,50 & 0 & 1 \\
\hline
\end{tabular}

Notes: all information is based on un-logarithmized values. 
Table A.2: Correlation matrix; based on basic model (column (9) of Table 2; N=1987)

\begin{tabular}{l|cccccc} 
& $\begin{array}{c}\text { Green product } \\
\text { innovation } \\
\text { intensity }\end{array}$ & Taxes & Regulations & $\begin{array}{c}\text { Public } \\
\text { subsidies }\end{array}$ & $\begin{array}{c}\text { Voluntary } \\
\text { agreements }\end{array}$ & Demand \\
\hline Taxes & $-0,02$ & & & & & \\
Regulations & 0,03 & 0,51 & & & & \\
Public subsidies & 0,08 & 0,37 & 0,55 & & & \\
Voluntary agreements & 0,16 & 0,32 & 0,39 & 0,44 & & \\
Demand & 0,25 & 0,12 & 0,24 & 0,29 & 0,46 & \\
Export intensity & 0,10 & 0,12 & 0,10 & 0,08 & 0,03 & $-0,05$ \\
Share of high qualified employees & 0,06 & $-0,14$ & $-0,13$ & $-0,10$ & $-0,04$ & 0,04 \\
Foreign owned & 0,03 & 0,05 & 0,09 & 0,07 & $-0,01$ & $-0,02$ \\
Firm age & 0,03 & 0,08 & 0,12 & 0,09 & 0,02 & 0,02 \\
Competition intensity & 0,01 & 0,00 & 0,04 & 0,02 & 0,01 & 0,04 \\
R\&D propensity & 0,16 & 0,02 & 0,04 & 0,07 & 0,06 & 0,02 \\
Green process innovation intensity & 0,13 & 0,23 & 0,22 & 0,23 & 0,26 & 0,14 \\
Products not suited & $-0,08$ & 0,02 & 0,03 & 0,05 & $-0,02$ & $-0,06$ \\
Number of employees & 0,11 & 0,18 & 0,21 & 0,19 & 0,14 & 0,10 \\
Swiss firm & 0,01 & $-0,09$ & 0,10 & 0,03 & $-0,07$ & $-0,01$ \\
German firm & $-0,06$ & 0,10 & $-0,09$ & $-0,03$ & 0,04 & 0,02
\end{tabular}

\begin{tabular}{|c|c|c|c|c|c|c|}
\hline & $\begin{array}{c}\text { Export } \\
\text { intensity }\end{array}$ & $\begin{array}{l}\text { Share of high } \\
\text { qualified } \\
\text { employees }\end{array}$ & $\begin{array}{c}\text { Foreign } \\
\text { owned }\end{array}$ & Firm age & $\begin{array}{c}\text { Competition } \\
\text { intensity }\end{array}$ & $\begin{array}{c}\mathrm{R} \& \mathrm{D} \\
\text { propensity }\end{array}$ \\
\hline Share of high qualified employees & 0,09 & & & & & \\
\hline Foreign owned & 0,28 & 0,02 & & & & \\
\hline Firm age & 0,09 & $-0,25$ & 0,07 & & & \\
\hline Competition intensity & $-0,22$ & $-0,13$ & $-0,13$ & 0,05 & & \\
\hline R\&D propensity & 0,42 & 0,27 & 0,10 & $-0,04$ & $-0,20$ & \\
\hline Green process innovation intensity & 0,20 & $-0,02$ & 0,08 & 0,12 & $-0,05$ & 0,20 \\
\hline Products not suited & 0,04 & $-0,05$ & 0,00 & 0,01 & 0,00 & 0,05 \\
\hline Number of employees & 0,38 & $-0,06$ & 0,25 & 0,34 & $-0,06$ & 0,26 \\
\hline Swiss firm & $-0,04$ & $-0,29$ & 0,11 & 0,39 & 0,15 & $-0,14$ \\
\hline German firm & $-0,06$ & 0,33 & $-0,16$ & $-0,40$ & $-0,10$ & 0,08 \\
\hline
\end{tabular}

\begin{tabular}{l|cccc} 
& $\begin{array}{c}\text { Green process } \\
\text { innovation } \\
\text { intensity }\end{array}$ & $\begin{array}{c}\text { Products } \\
\text { not suited }\end{array}$ & $\begin{array}{c}\text { Number of } \\
\text { employees }\end{array}$ & Swiss firm \\
\hline Products not suited & 0,01 & & & \\
Number of employees & 0,29 & 0,01 & & \\
Swiss firm & $-0,07$ & 0,06 & 0,13 & \\
German firm & 0,03 & $-0,06$ & $-0,20$ & $-0,86$
\end{tabular}


Table A.3: Testing the effect of policy stringency (Tobit regressions)

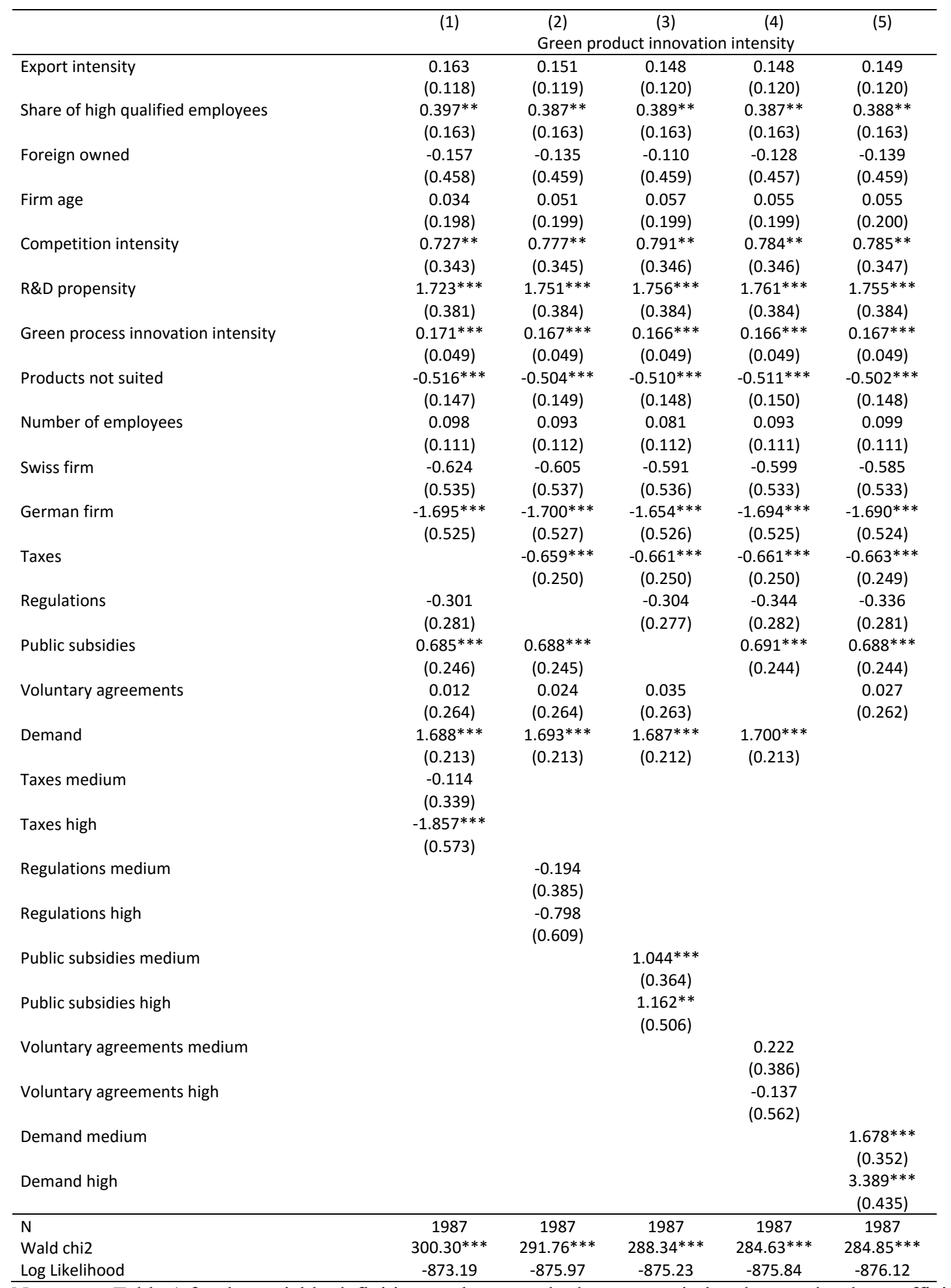

Notes: see Table 1 for the variable definitions; robust standard errors are in brackets under the coefficients; ***, **, $*,+$ denote statistical significance at the $1 \%, 5 \%, 10 \%$ and $15 \%$ test level, respectively; all models include a constant term. 
Table A.4: Test alternative dependent variables and estimation procedures

\begin{tabular}{|c|c|c|c|}
\hline & $\begin{array}{c}\text { (1) } \\
\text { Green product innovation } \\
\text { intensity } \\
\text { OLS }\end{array}$ & $\begin{array}{c}\text { (2) } \\
\text { Green product innovation } \\
\text { propensity } \\
\text { Probit }\end{array}$ & $\begin{array}{c}\text { (3) } \\
\text { Green R\&D } \\
\text { propensity } \\
\text { Probit }\end{array}$ \\
\hline Export intensity & $\begin{array}{c}0.012 \\
(0.013)\end{array}$ & $\begin{array}{c}0.005 \\
(0.032)\end{array}$ & $\begin{array}{l}0.061+ \\
(0.040)\end{array}$ \\
\hline Share of high qualified & $\begin{array}{l}0.029 * \\
(0.016)\end{array}$ & $\begin{array}{l}0.073^{*} \\
(0.043)\end{array}$ & $\begin{array}{c}0.200 * * * \\
(0.054)\end{array}$ \\
\hline Foreign owned & $\begin{array}{l}-0.005 \\
(0.063)\end{array}$ & $\begin{array}{l}-0.034 \\
(0.127)\end{array}$ & $\begin{array}{l}-0.285^{*} \\
(0.150)\end{array}$ \\
\hline Firm age & $\begin{array}{l}-0.002 \\
(0.023)\end{array}$ & $\begin{array}{c}0.028 \\
(0.054)\end{array}$ & $\begin{array}{c}0.000 \\
(0.063)\end{array}$ \\
\hline Competition intensity & $\begin{array}{l}0.087^{* *} \\
(0.041)\end{array}$ & $\begin{array}{l}0.201^{* *} \\
(0.094)\end{array}$ & $\begin{array}{c}0.080 \\
(0.106)\end{array}$ \\
\hline R\&D propensity & $\begin{array}{c}0.152^{* * *} \\
(0.040)\end{array}$ & $\begin{array}{c}0.530 * * * \\
(0.102)\end{array}$ & \\
\hline Green process innovation & $\begin{array}{c}0.017 * * * \\
(0.006)\end{array}$ & $\begin{array}{c}0.044^{* * *} \\
(0.014)\end{array}$ & $\begin{array}{c}0.056 * * * \\
(0.015)\end{array}$ \\
\hline Products not suited & $\begin{array}{c}-0.055^{* * *} \\
(0.011)\end{array}$ & $\begin{array}{c}-0.092 * * \\
(0.037)\end{array}$ & $\begin{array}{c}-0.192 * * * \\
(0.050)\end{array}$ \\
\hline Number of employees & $\begin{array}{c}0.007 \\
(0.016)\end{array}$ & $\begin{array}{c}0.090 * * * \\
(0.031)\end{array}$ & $\begin{array}{c}0.130 * * * \\
(0.034)\end{array}$ \\
\hline Swiss firm & $\begin{array}{l}-0.129 \\
(0.097)\end{array}$ & $\begin{array}{l}-0.114 \\
(0.157)\end{array}$ & $\begin{array}{l}-0.322^{*} \\
(0.179)\end{array}$ \\
\hline German firm & $\begin{array}{c}-0.230 * * \\
(0.096)\end{array}$ & $\begin{array}{l}-0.014 \\
(0.154)\end{array}$ & $\begin{array}{l}-0.270+ \\
(0.176)\end{array}$ \\
\hline Taxes & $\begin{array}{c}-0.059 * * \\
(0.027)\end{array}$ & $\begin{array}{l}-0.119 * \\
(0.068)\end{array}$ & $\begin{array}{c}-0.115+ \\
(0.078)\end{array}$ \\
\hline Regulations & $\begin{array}{l}-0.049 \\
(0.035)\end{array}$ & $\begin{array}{l}-0.145^{*} \\
(0.078)\end{array}$ & $\begin{array}{l}-0.114 \\
(0.098)\end{array}$ \\
\hline Public subsidies & $\begin{array}{l}0.070^{* *} \\
(0.036)\end{array}$ & $\begin{array}{l}0.174^{* *} \\
(0.068)\end{array}$ & $\begin{array}{l}0.118+ \\
(0.082)\end{array}$ \\
\hline Voluntary agreements & $\begin{array}{c}0.021 \\
(0.041)\end{array}$ & $\begin{array}{l}-0.018 \\
(0.080)\end{array}$ & $\begin{array}{l}-0.010 \\
(0.089)\end{array}$ \\
\hline Demand & $\begin{array}{c}0.267 * * * \\
(0.044)\end{array}$ & $\begin{array}{c}0.522 * * * \\
(0.064)\end{array}$ & $\begin{array}{c}0.428 * * * \\
(0.074)\end{array}$ \\
\hline $\mathrm{N}$ & 1987 & 1987 & 1987 \\
\hline $\begin{array}{l}\text { R2 } \\
\text { adj R2 }\end{array}$ & $\begin{array}{l}0.14 \\
0.12\end{array}$ & & \\
\hline pseudo R2 & & 0.21 & 0.24 \\
\hline Wald chi2 & & $3061.51 * * *$ & $2702.44^{* * *}$ \\
\hline Log Likelihood & -2200.34 & -633.60 & -413.02 \\
\hline
\end{tabular}


Table A.5: Test robustness of results for specific sub-samples (Tobit regressions)

\begin{tabular}{|c|c|c|}
\hline \multirow[b]{3}{*}{ Sample restriction: } & (1) & (2) \\
\hline & \multicolumn{2}{|c|}{ Green product innovation intensity } \\
\hline & $\begin{array}{c}\text { Firms that had discussions } \\
\text { about the creation of green } \\
\text { products/services }\end{array}$ & $\begin{array}{l}\text { Firms with products/services } \\
\text { that are suited for green product } \\
\text { innovation }\end{array}$ \\
\hline \multirow[t]{2}{*}{ Export intensity } & 0.093 & 0.137 \\
\hline & $(0.115)$ & $(0.121)$ \\
\hline \multirow{2}{*}{ Share of high qualified employees } & $0.368 * *$ & $0.371 * *$ \\
\hline & $(0.170)$ & (0.166) \\
\hline \multirow[t]{2}{*}{ Foreign owned } & 0.007 & -0.095 \\
\hline & $(0.432)$ & $(0.475)$ \\
\hline \multirow[t]{2}{*}{ Firm age } & -0.074 & 0.025 \\
\hline & $(0.204)$ & $(0.206)$ \\
\hline \multirow{2}{*}{ Competition intensity } & $0.638^{*}$ & $0.752^{* *}$ \\
\hline & $(0.342)$ & $(0.356)$ \\
\hline \multirow{2}{*}{ R\&D propensity } & $0.989 * * *$ & $1.734 * * *$ \\
\hline & $(0.367)$ & $(0.394)$ \\
\hline \multirow{2}{*}{ Green process innovation intensity } & $0.088^{*}$ & $0.179 * * *$ \\
\hline & (0.049) & $(0.050)$ \\
\hline \multirow[t]{2}{*}{ Products not suited } & $-1.018 * * *$ & -0.188 \\
\hline & (0.161) & $(0.208)$ \\
\hline \multirow[t]{2}{*}{ Number of employees } & 0.050 & 0.121 \\
\hline & (0.110) & (0.113) \\
\hline \multirow[t]{2}{*}{ Swiss firm } & 0.277 & -0.525 \\
\hline & (0.474) & $(0.556)$ \\
\hline \multirow[t]{2}{*}{ German firm } & $-1.486 * * *$ & $-1.766 * * *$ \\
\hline & $(0.468)$ & $(0.545)$ \\
\hline \multirow[t]{2}{*}{ Taxes } & $-0.551 * *$ & $-0.729 * * *$ \\
\hline & $(0.239)$ & $(0.258)$ \\
\hline \multirow{2}{*}{ Regulations } & -0.247 & -0.259 \\
\hline & $(0.269)$ & $(0.297)$ \\
\hline \multirow[t]{2}{*}{ Public subsidies } & $0.588 * * *$ & $0.622^{* *}$ \\
\hline & $(0.227)$ & $(0.252)$ \\
\hline \multirow[t]{2}{*}{ Voluntary agreements } & -0.197 & 0.141 \\
\hline & $(0.250)$ & (0.274) \\
\hline \multirow{2}{*}{ Demand } & $0.988 * * *$ & $1.689 * * *$ \\
\hline & $(0.209)$ & $(0.220)$ \\
\hline $\mathrm{N}$ & 847 & 1698 \\
\hline Wald chi2 & $154.03 * * *$ & $287.05^{* * *}$ \\
\hline Log Likelihood & -662.84 & -823.11 \\
\hline
\end{tabular}


Table A.6: Test differences between countries (Tobit regressions)

\begin{tabular}{|c|c|c|c|c|c|c|}
\hline \multirow{4}{*}{$\begin{array}{l}\text { Country: } \\
\text { Export intensity }\end{array}$} & (1) & (2) & (3) & (4) & (5) & (6) \\
\hline & \multicolumn{6}{|c|}{ Green product innovation intensity } \\
\hline & \multicolumn{2}{|c|}{ Switzerland } & \multicolumn{2}{|c|}{ Germany } & \multicolumn{2}{|c|}{ Austria } \\
\hline & 0.045 & 0.054 & 0.201 & 0.216 & 0.173 & 0.183 \\
\hline & $(0.169)$ & $(0.167)$ & $(0.191)$ & $(0.192)$ & $(0.386)$ & $(0.362)$ \\
\hline \multirow[t]{2}{*}{ Share of high qualified employees } & 0.345 & $0.362 *$ & 0.441 & 0.454 & 0.464 & 0.458 \\
\hline & $(0.220)$ & $(0.219)$ & $(0.285)$ & $(0.287)$ & $(0.433)$ & $(0.435)$ \\
\hline \multirow[t]{2}{*}{ Foreign owned } & -0.428 & -0.460 & 0.049 & 0.049 & 0.395 & 0.257 \\
\hline & $(0.554)$ & $(0.556)$ & $(1.049)$ & $(1.047)$ & $(0.879)$ & $(0.897)$ \\
\hline \multirow[t]{2}{*}{ Firm age } & -0.259 & -0.262 & 0.352 & 0.325 & 0.159 & 0.073 \\
\hline & $(0.286)$ & $(0.279)$ & $(0.334)$ & $(0.336)$ & $(0.464)$ & $(0.500)$ \\
\hline \multirow[t]{2}{*}{ Competition intensity } & 0.534 & 0.557 & 0.860 & 0.828 & $1.907^{* *}$ & $2.146^{* *}$ \\
\hline & $(0.523)$ & $(0.526)$ & $(0.536)$ & $(0.536)$ & $(0.924)$ & $(0.892)$ \\
\hline \multirow[t]{2}{*}{ R\&D propensity } & $2.123 * * *$ & $2.067 * * *$ & $1.661 * * *$ & $1.649 * *$ & 1.344 & 1.609 \\
\hline & $(0.507)$ & $(0.515)$ & $(0.639)$ & $(0.641)$ & $(1.124)$ & $(1.183)$ \\
\hline \multirow[t]{2}{*}{ Green process innovation intensity } & $0.232 * * *$ & $0.238 * * *$ & 0.114 & 0.114 & 0.012 & 0.020 \\
\hline & $(0.062)$ & $(0.063)$ & $(0.089)$ & $(0.089)$ & $(0.123)$ & $(0.124)$ \\
\hline \multirow[t]{2}{*}{ Products not suited } & $-0.512 * * *$ & $-0.524 * * *$ & -0.380 & -0.398 & $-1.068 * *$ & $-1.035^{* *}$ \\
\hline & $(0.178)$ & $(0.182)$ & $(0.259)$ & $(0.260)$ & $(0.431)$ & $(0.429)$ \\
\hline \multirow[t]{2}{*}{ Number of employees } & $0.506 * * *$ & $0.499 * * *$ & -0.186 & -0.183 & 0.115 & -0.000 \\
\hline & $(0.184)$ & $(0.181)$ & $(0.171)$ & $(0.171)$ & $(0.404)$ & $(0.402)$ \\
\hline \multirow[t]{2}{*}{ Taxes } & -0.163 & -0.318 & $-1.161 * * *$ & & -0.012 & -0.181 \\
\hline & $(0.369)$ & $(0.328)$ & $(0.411)$ & & $(0.853)$ & $(0.616)$ \\
\hline \multirow[t]{2}{*}{ Taxes medium } & & & & -0.527 & & \\
\hline & & & & $(0.563)$ & & \\
\hline \multirow[t]{2}{*}{ Taxes high } & & & & $-2.801 * * *$ & & \\
\hline & & & & (0.917) & & \\
\hline \multirow[t]{2}{*}{ Regulations } & -0.355 & & -0.758 & -0.720 & -0.823 & \\
\hline & $(0.385)$ & & $(0.509)$ & (0.509) & $(0.847)$ & \\
\hline \multirow[t]{2}{*}{ Public subsidies } & $0.595^{*}$ & & $0.799 *$ & $0.842 * *$ & 0.626 & \\
\hline & $(0.350)$ & & $(0.412)$ & $(0.413)$ & (0.669) & \\
\hline \multirow[t]{2}{*}{ Voluntary agreements } & -0.282 & & 0.522 & 0.521 & -0.169 & \\
\hline & $(0.353)$ & & (0.479) & $(0.479)$ & $(0.732)$ & \\
\hline \multirow[t]{2}{*}{ Demand } & $1.586^{* * *}$ & $1.700 * * *$ & $2.018 * * *$ & $1.998 * * *$ & $1.252^{* *}$ & $1.217^{* *}$ \\
\hline & $(0.278)$ & $(0.254)$ & $(0.408)$ & $(0.407)$ & $(0.607)$ & $(0.565)$ \\
\hline Industry controls & yes & yes & yes & yes & yes & yes \\
\hline $\mathrm{N}$ & 873 & 873 & 964 & 964 & 150 & 150 \\
\hline Wald chi2 & $353.30 * * *$ & $309.18^{* * *}$ & $124.93 * * *$ & $127.46 * * *$ & $100.72 * * *$ & $76.62 * * *$ \\
\hline Log Likelihood & -400.25 & -401.94 & -356.63 & -355.36 & -95.74 & -96.51 \\
\hline
\end{tabular}

Notes: see Table 1 for the variable definitions; standard errors are in brackets under the coefficients; ***, **, *, + denote statistical significance at the $1 \%, 5 \%, 10 \%$ and $15 \%$ test level, respectively; all models include a constant term. 
Table A.7: Restrict sample to firms with green R\&D activities (Tobit regressions)

\begin{tabular}{|c|c|c|c|c|c|c|c|c|c|}
\hline & (1) & (2) & (3) & (4) & (5) & (6) & (7) & (8) & (9) \\
\hline & \multicolumn{9}{|c|}{ Green product innovation intensity } \\
\hline Export intensity & $\begin{array}{c}0.119 \\
(0.099)\end{array}$ & $\begin{array}{c}0.135 \\
(0.098)\end{array}$ & $\begin{array}{c}0.139 \\
(0.098)\end{array}$ & $\begin{array}{l}0.147+ \\
(0.097)\end{array}$ & $\begin{array}{c}0.131 \\
(0.100)\end{array}$ & $\begin{array}{c}0.137 \\
(0.099)\end{array}$ & $\begin{array}{c}0.115 \\
(0.098)\end{array}$ & $\begin{array}{c}0.131 \\
(0.097)\end{array}$ & $\begin{array}{l}0.153+ \\
(0.099)\end{array}$ \\
\hline Share of high qualified & $\begin{array}{c}0.258+ \\
(0.160)\end{array}$ & $\begin{array}{l}0.305^{*} \\
(0.156)\end{array}$ & $\begin{array}{c}0.224 \\
(0.160)\end{array}$ & $\begin{array}{l}0.273^{*} \\
(0.157)\end{array}$ & $\begin{array}{c}0.209 \\
(0.168)\end{array}$ & $\begin{array}{l}0.255+ \\
(0.162)\end{array}$ & $\begin{array}{l}0.254+ \\
(0.160)\end{array}$ & $\begin{array}{l}0.299 * \\
(0.156)\end{array}$ & $\begin{array}{c}0.231 \\
(0.162)\end{array}$ \\
\hline Foreign owned & $\begin{array}{c}-0.216 \\
(0.367)\end{array}$ & $\begin{array}{c}-0.062 \\
(0.346)\end{array}$ & $\begin{array}{c}-0.171 \\
(0.358)\end{array}$ & $\begin{array}{l}-0.043 \\
(0.344)\end{array}$ & $\begin{array}{c}-0.057 \\
(0.368)\end{array}$ & $\begin{array}{l}-0.003 \\
(0.355)\end{array}$ & $\begin{array}{c}-0.198 \\
(0.366)\end{array}$ & $\begin{array}{c}-0.063 \\
(0.348)\end{array}$ & $\begin{array}{c}-0.005 \\
(0.361)\end{array}$ \\
\hline Firm age & $\begin{array}{c}-0.070 \\
(0.179)\end{array}$ & $\begin{array}{c}-0.098 \\
(0.170)\end{array}$ & $\begin{array}{l}-0.011 \\
(0.170)\end{array}$ & $\begin{array}{l}-0.044 \\
(0.165)\end{array}$ & $\begin{array}{c}0.008 \\
(0.166)\end{array}$ & $\begin{array}{l}-0.030 \\
(0.164)\end{array}$ & $\begin{array}{c}-0.048 \\
(0.172)\end{array}$ & $\begin{array}{c}-0.079 \\
(0.165)\end{array}$ & $\begin{array}{c}-0.007 \\
(0.171)\end{array}$ \\
\hline Competition intensity & $\begin{array}{c}0.155 \\
(0.282)\end{array}$ & $\begin{array}{c}0.060 \\
(0.271)\end{array}$ & $\begin{array}{c}0.205 \\
(0.277)\end{array}$ & $\begin{array}{c}0.109 \\
(0.267)\end{array}$ & $\begin{array}{c}0.155 \\
(0.273)\end{array}$ & $\begin{array}{c}0.091 \\
(0.269)\end{array}$ & $\begin{array}{c}0.166 \\
(0.282)\end{array}$ & $\begin{array}{c}0.068 \\
(0.272)\end{array}$ & $\begin{array}{c}0.116 \\
(0.268)\end{array}$ \\
\hline R\&D propensity & $\begin{array}{c}0.069 \\
(0.375)\end{array}$ & $\begin{array}{c}0.138 \\
(0.349)\end{array}$ & $\begin{array}{c}0.034 \\
(0.366)\end{array}$ & $\begin{array}{c}0.105 \\
(0.345)\end{array}$ & $\begin{array}{l}-0.010 \\
(0.370)\end{array}$ & $\begin{array}{c}0.062 \\
(0.359)\end{array}$ & $\begin{array}{c}0.030 \\
(0.373)\end{array}$ & $\begin{array}{c}0.124 \\
(0.353)\end{array}$ & $\begin{array}{c}0.093 \\
(0.356)\end{array}$ \\
\hline Green process innovation & $\begin{array}{c}-0.027 \\
(0.044)\end{array}$ & $\begin{array}{c}-0.057 \\
(0.045)\end{array}$ & $\begin{array}{l}-0.037 \\
(0.044)\end{array}$ & $\begin{array}{c}-0.061 \\
(0.045)\end{array}$ & $\begin{array}{c}-0.054 \\
(0.043)\end{array}$ & $\begin{array}{c}-0.064+ \\
(0.043)\end{array}$ & $\begin{array}{c}-0.023 \\
(0.043)\end{array}$ & $\begin{array}{c}-0.051 \\
(0.044)\end{array}$ & $\begin{array}{c}-0.071+ \\
(0.045)\end{array}$ \\
\hline Products not suited & $\begin{array}{c}-0.320^{*} \\
(0.167)\end{array}$ & $\begin{array}{c}-0.304^{*} \\
(0.160)\end{array}$ & $\begin{array}{c}-0.329 * * \\
(0.167)\end{array}$ & $\begin{array}{c}-0.311^{*} \\
(0.162)\end{array}$ & $\begin{array}{c}-0.351 * * \\
(0.162)\end{array}$ & $\begin{array}{c}-0.327^{* *} \\
(0.158)\end{array}$ & $\begin{array}{c}-0.318^{*} \\
(0.166)\end{array}$ & $\begin{array}{c}-0.296^{*} \\
(0.158)\end{array}$ & $\begin{array}{c}-0.329 * * \\
(0.158)\end{array}$ \\
\hline Number of employees & $\begin{array}{c}-0.163^{*} \\
(0.097)\end{array}$ & $\begin{array}{c}-0.183^{*} \\
(0.095)\end{array}$ & $\begin{array}{c}-0.196 * * \\
(0.095)\end{array}$ & $\begin{array}{c}-0.206 * * \\
(0.095)\end{array}$ & $\begin{array}{c}-0.162^{*} \\
(0.088)\end{array}$ & $\begin{array}{c}-0.174 * * \\
(0.089)\end{array}$ & $\begin{array}{c}-0.160^{*} \\
(0.093)\end{array}$ & $\begin{array}{c}-0.176^{*} \\
(0.092)\end{array}$ & $\begin{array}{c}-0.196 * * \\
(0.094)\end{array}$ \\
\hline Swiss firm & $\begin{array}{c}-0.274 \\
(0.342)\end{array}$ & $\begin{array}{c}-0.395 \\
(0.343)\end{array}$ & $\begin{array}{c}-0.489 \\
(0.359)\end{array}$ & $\begin{array}{c}-0.554+ \\
(0.360)\end{array}$ & $\begin{array}{l}-0.338 \\
(0.329)\end{array}$ & $\begin{array}{l}-0.403 \\
(0.334)\end{array}$ & $\begin{array}{c}-0.287 \\
(0.345)\end{array}$ & $\begin{array}{c}-0.401 \\
(0.342)\end{array}$ & $\begin{array}{c}-0.543+ \\
(0.360)\end{array}$ \\
\hline German firm & $\begin{array}{c}- \\
(0.366)\end{array}$ & $\begin{array}{c}- \\
(0.363)\end{array}$ & $\begin{array}{c}- \\
(0.375)\end{array}$ & $\begin{array}{c}- \\
(0.372)\end{array}$ & $\begin{array}{c}- \\
(0.350)\end{array}$ & $\begin{array}{c}- \\
(0.353)\end{array}$ & $\begin{array}{c}- \\
(0.368)\end{array}$ & $\begin{array}{c}- \\
(0.365)\end{array}$ & $\begin{array}{c}- \\
(0.364)\end{array}$ \\
\hline Taxes & $\begin{array}{c}0.132 \\
(0.236)\end{array}$ & $\begin{array}{c}0.129 \\
(0.228)\end{array}$ & & & & & & & $\begin{array}{c}0.004 \\
(0.247)\end{array}$ \\
\hline Regulations & & & $\begin{array}{c}0.435 * * \\
(0.209)\end{array}$ & $\begin{array}{l}0.344+ \\
(0.210)\end{array}$ & & & & & $\begin{array}{c}0.317 \\
(0.248)\end{array}$ \\
\hline Public subsidies & & & & & $\begin{array}{c}0.470 * * \\
(0.163)\end{array}$ & $\begin{array}{l}0.321 * \\
(0.174)\end{array}$ & & & $\begin{array}{l}0.317+ \\
(0.208)\end{array}$ \\
\hline Voluntary agreements & & & & & & & $\begin{array}{c}0.142 \\
(0.180)\end{array}$ & $\begin{array}{c}0.048 \\
(0.173)\end{array}$ & $\begin{array}{l}-0.204 \\
(0.201)\end{array}$ \\
\hline Demand & & $\begin{array}{c}0.458 * * \\
(0.171)\end{array}$ & & $\begin{array}{c}0.414 * * \\
(0.176)\end{array}$ & & $\begin{array}{l}0.315^{*} \\
(0.188)\end{array}$ & & $\begin{array}{c}0.452 * * \\
(0.175)\end{array}$ & $\begin{array}{l}0.308^{*} \\
(0.186)\end{array}$ \\
\hline Industry controls & yes & yes & yes & yes & yes & yes & yes & yes & yes \\
\hline $\begin{array}{l}\mathrm{N} \\
\text { Wald chi2 } \\
\text { Log Likelihood }\end{array}$ & $\begin{array}{c}155 \\
157.10^{*} \\
-250.61\end{array}$ & $\begin{array}{c}155 \\
166.55^{*} \\
-246.70\end{array}$ & $\begin{array}{c}155 \\
159.44^{*} \\
-248.70\end{array}$ & $\begin{array}{c}155 \\
162.26^{*} \\
-245.57\end{array}$ & $\begin{array}{c}155 \\
184.79 * \\
-246.93\end{array}$ & $\begin{array}{c}155 \\
185.79 * \\
-245.44\end{array}$ & $\begin{array}{c}155 \\
160.27^{*} \\
-250.51\end{array}$ & $\begin{array}{c}155 \\
169.35^{*} \\
-24687\end{array}$ & $\begin{array}{c}155 \\
183.75^{*} \\
-24435\end{array}$ \\
\hline
\end{tabular}

